\title{
Inferring denudation variations from the sediment record; an example of the last glacial cycle record of the Golo Basin and watershed, East Corsica, western Mediterranean sea
}

\author{
G. Calvès ${ }^{1,2,3,{ }^{*},}$ S. Toucanne ${ }^{3}$, G. Jouet $^{3}$, S. Charrier ${ }^{3}$, E. Thereau ${ }^{3}$, J. Etoubleau $^{3}$, T. Marsset $^{3}$,

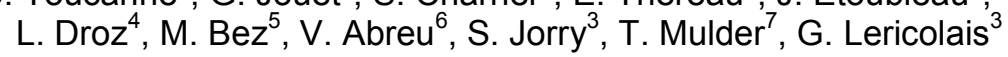

\author{
${ }^{1}$ GET, Université Toulouse 3, Paul-Sabatier, Toulouse, France \\ 2 Basin Studies and Petroleum Geoscience, Atmospheric and Environmental Sciences, School of Earth, \\ The Manchester University, Manchester, UK \\ 3 IFREMER, Géosciences Marines, Laboratoire Environnements Sédimentaires, Plouzané, France \\ ${ }^{4}$ UMR-CNRS 6538, Institut Universitaire Européen de la Mer, Plouzané, France \\ ${ }^{5}$ TOTAL, Pau, France \\ ${ }_{7}^{6}$ ExxonMobil Exploration Company, Houston, TX, USA \\ ${ }^{7}$ Université Bordeaux 1, Bâtiment "Recherche Géologie" B18, Talence, Cedex, France \\ *: Corresponding author : G. Calvès, email address : gerome.calves@get.obs-mip.fr
}

\begin{abstract}
:
Geophysical data and sampling of the Golo Basin (East Corsica margin) provide the opportunity to study mass balance in a single drainage system over the last $130 \mathrm{kyr}$, by comparing deposited sediments in the sink and the maximum eroded volume in the source using total denudation proxies. Evaluation of the solid sediments deposited offshore and careful integration of uncertainties from the age model and physical properties allow us to constrain three periods of sedimentation during the last climatic cycle. The peak of sedimentation initiated during Marine Isotopic Stage (MIS) 3 (ca. $45 \mathrm{ka}$ ) and lasted until late in MIS 2 (ca. $18 \mathrm{ka}$ ). This correlates with Mediterranean Sea palaeoclimatic records and the glaciation in high altitude Corsica. The yield of solid sediment into the Golo Basin drops in the observed present day Mediterranean basins (gauging stations), whereas the palaeodenudation estimate derived from the sediments over the last glacial period is one to ten times higher than that predicted using cosmogenic or thermochronometer estimates of exhumation. The catchmentwide denudation rate calculated from deposited solid sediment ranges from 47 to $219 \mathrm{~mm} \mathrm{kyr}^{-1}$, which is higher than the estimate from palaeosurface ablation in the proximal part of the source (9$140 \mathrm{~mm} \mathrm{kyr}^{-1}$ ) and lower than the distal, narrow, incised channel of the Golo River (160$\left.475 \mathrm{~mm} \mathrm{kyr}^{-1}\right)$. This mismatch raises questions about the investigation of denudation at millennial-time scale (kyr) and at higher integrating times (Myr) as a reliable tool for determining the effect of climate change on mountain building and on sedimentary basin models.
\end{abstract}


Tectonic forces (uplift or subsidence), and climate changes (green or ice-house periods), have affected and/or controlled, through erosion and sedimentation, the history of the Earth surface over different time periods at local or global distance scales [e.g., Davies et al., 1977; Allen, 1997, Allen, 2005, and references within]. The Earth science community analyses these issues from a number of different perspectives. One is based on onshore studies, including denudation and relief generation (e.g., rock uplift, erosion, river runoff, glaciations, paleo-altitude). A second focuses on the records preserved in marine or lake sediments (e.g., via sedimentary processes, solid sediment accumulation, paleoclimatic reconstruction). A holistic approach aims to frame these two perspectives as parts of a continuum.

One approach to reconstructing erosion involves calibrating present day fluxes of rivers and catchment parameters (e.g., discharge, run-off, drainage area). This has been used to classify and constrain processes such as climatic variations, uplift, and yield of sediment from hinterland to the ocean [Milliman and Syvitski, 1992; Hovius, 1998; Kettner and Syvitski, 2008]. It has been noted by Syvitski and Morehead [1999] that long-term sediment flux to the margin directly depends on the water discharge and hydrology of contributing rivers, the latter being controlled by climate and drainage basin characteristics (geomorphology-relief, soil-vegetation, sedimentary cover, basement type). Prediction of sediment yield from source to sink has been tested and modeled using a global data set and resulted in predictive models such as BQART [e.g., Syvitksi and Milliman, 2007]. This model has been used over the last $80 \mathrm{kyr}$ to estimate the paleo-sediment flux of the Golo catchment to the Mediterranean Sea (Fig. 1A) [Sømme et al., 2011]. From their estimate of sediments in the offshore sink they estimate an overestimate of $16 \%$ from this model.

A major challenge in quantifying sediment flux to the ocean resides in the timescale over which we choose to integrate [e.g., von Blanckenburg, 2005; Lisker et al., 2009]. We can use thermochronometers such as apatite fission track (AFT; long term, $10^{6} \mathrm{yr}$ ), cosmogenic isotopes ${ }^{10} \mathrm{Be}$ [Willenbring and von Blanckenburg, 2010], thermoluninescence techniques like Optical Stimulated Luminescence (OSL) [Rittenour et al., 2008] (short term, $10^{3} \mathrm{yr}$ ), or present day river load data (instantaneous, seasonal) to constrain denudation (mechanical or chemical). However, an alternative answer lies in the preserved sediments within basins located between the continent and the ocean. These marine or lacustrine sedimentary archives can be used to reconstruct past climatic variations and link induced atmospheric and solid Earth processes. The record of past climatic changes has been unraveled by the analysis of ice- and sediment cores at the global scale using isotopic information and biosphere proxies [Grootes et al., 1993; Shackleton et al., 2000; Lisiecki and Raymo, 2005]. However, the relationship between the inferring climatic changes and the relief building using AFT record is not fully established, mainly due to the fairly low resolution timing [e.g., Willett et al., 2006; Valla et al., 2010; Van Der Beek et al., 2010].

The last climatic cycle, since $130 \mathrm{ka}$, and even higher frequency cycles are still the focus of numerous studies; the scattered locations and the improvement of the analytical techniques allow to reconstruct the sub-surface stratigraphy with higher resolution (i.e., time, duration of events). The extent of the glacial cover and the erosive power of the processes operating during the advance and retreat of the ice-front at the scale of the northern hemisphere is acknowledged as playing an important part in denudation at the Earth's surface [e.g., de Martonne, 1910]. For example, the high rates of sediment export to the ocean caused by catastrophic events in Northern Europe involved ancient rivers (e.g. the Fleuve Manche palaeoriver) directly controlled by the continental scale ice-sheets "pulses" [Toucanne et al., 2010]. Recent studies either onshore or offshore also highlighted the role played by glaciers in destabilization and denudation of the Alps over the last glacial period [Florineth and Schluchter, 1998; Hinderer, 2001; Norton et al., 2010; Jorry et al., 2011]. In this region the 
Mediterranean island of Corsica represents a key study area for the Würmian time (120-10 kyr) where the anomalous steep gradients of the regional equilibrium line altitude made the Corsica drainage basins highly sensitive to even moderate paleoclimate changes [Kuhlemann et al., 2008].

The aim of this paper is to reconstruct the flux of solid sediment $\left(\mathrm{Qs}, \mathrm{m}^{3} / \mathrm{yr}\right.$ ) preserved offshore the Golo Basin, and, to quantify mass fluxes from source to sink during the last $\sim 130$ kyr. To do this we have integrated set of data from subsurface 2D seismic reflection data and stratigraphic information including, core samples (lithology and physical properties) combined with age calibration and geochemical analysis. The evolution of the sedimentary succession offshore is compared with estimates of onshore denudation rates derived from previously published fission track, cosmogenic and river/terrace incision studies. We assess whether there is a long term balance between eroded rocks in the source area and the amount of sediment preserved in the depositional basin. We discuss which factors control the erosion of Corsica throughout the sedimentary record. The evolution of the sediment routing system of a unique source-to-sink system located within the western Mediterranean Sea (Fig. 1A) allows us to discuss the forcing parameters such as paleo-climate and tectonic processes.

\section{Previous studies - Regional setting}

\subsection{The onshore perspective}

The onshore Golo catchment covers an area of $1214 \mathrm{~km}^{2}$ and it is drained by the Golo River (86.9 $\mathrm{km}$ long) that captures the La Casaluna tributary $(25.3 \mathrm{~km})$, the Asco tributary $(34.1$ $\mathrm{km})$, Tartagine tributary $(30.2 \mathrm{~km})$, and the Lagani creek $(22.1 \mathrm{~km})(F i g .1 \mathrm{~B}$ and $1 \mathrm{C})$. The Golo drainage is surrounded at its mouth by two coastal catchments, the Benvico to the north and the Fium Alto to the south.

The bedrock geology is composed of two different domains, Variscan and Alpine Corsica (Fig. 1B). Each of these domains shows contrasting rocks, with accreted Jurassic oceanic crust in the East and granitoïd rocks and basalt to the West (Fig. 1B). Shallow marine sedimentary basins are exposed onshore; most notably the Miocene Saint Florent Basin to the northeast, and the younger Aleria and Marana Plain located along the eastern coast. The recent evolution of the paleosurfaces exposed at high altitude in the central part of Corsica (Fig. 1C), as a result of young differential uplift, has been recently quantified using ${ }^{10} \mathrm{Be}$ cosmogenic methods [Kuhlemann et al., 2009]. Estimates of average denudation rate of 9 $140 \mathrm{~mm} / \mathrm{kyr}$ from this analysis (averaged over the last 100-30 ka) are consistent with the denudation estimates of $25-220 \mathrm{~mm} / \mathrm{kyr}$ derived from the thermal modeling of apatite fission-track data, which extend over the longer Neogene period (c. $20-3 \mathrm{Ma}$ )[Kuhlemann et al., 2009]. The Cenozoic evolution have been study using thermochronometry (e.g., apatite fission tracks) to frame the role of the Corsica-Sardinia blocks in the evolution of the Ligurian Sea and in Alpine tectonism [e.g., Lucazeau and Mailhe, 1986; Cavazza et al., 2001; ZarkiJakni et al., 2004; Fellin et al., 2005a, 2006; Danišik et al., 2007].

Contribution to denudation from hillslope gravitational processes (e.g.: rockfall, debris flowslides, rock-slide) in the Golo catchment is mainly focused toward the Alpine Corsica domain (Fig. 1C). This localization of events in the eastern part of Corsica contrast with the relative low frequency of mass movements in the Variscan domain. From a present-day observation of satellite images, these two domains contrast by the rare vegetation in the Variscan domain and dense cover in the Alpine domain. The historical seismicity in Corsica is limited to 19 records (Fig. 1C). Intensity of shakes range from 2.3 to 4.1 magnitude, with epicenter focal depth located from 2 to $30 \mathrm{~km}$ below surface. In comparison with the Apennines Belt towards the East [Cocco et al., 1993], this makes Corsica a quiet area in that part of the western 
Mediterranean Sea. From these two points, it is important to acknowledge that hillslopelandslides contribution compared to place like western southern Alps of New Zealand [Hovius et al., 1997], might not represent dominant contribution to the overall erosion budget of the Golo catchment. In comparison to other setting around the western Mediterranean Sea, the Golo system offers a 'stable tectonic' condition, allowing to focus on other processes when inferring controlling factors on denudation in the source and sedimentation in the sink areas.

The onshore Golo catchment shows little preserved alluvial record [Conchon, 1977]. The main occurrence of alluvial deposits occurs along the last $7.5 \mathrm{~km}$ of the Golo River (Fig. 1C) [Conchon, 1977, 1978; Lahondère et al., 1994]. These deposits (subdivided in N1 to N7 units by Conchon [1977]) have been assigned a Quaternary age. Terraces N2 to N6 have been documented, measured and dated by OSL dating by Sømme et al. [2011]. Note that the volumes documented by these authors are not corrected for porosity, volumetric estimates are from this study. The terraces N6 and N5 (volume: $0.33 \pm 0.11 \mathrm{~km}^{3} ; 0.34 \mathrm{~km}^{3}$ ) span age of deposit from 9.4 to $0.52 \mathrm{ka}$ (Table 4 in Sømme et al., 2011). These ages are then interpreted as minimum and attributed by Sømme et al., [2011] to Younger Dryas stadial for N6 and Marine Isotope Stage (MIS) 2 for N5 (32-17 ka in Figure 12 in Sømme et al., 2011). The N4 deposits $\left(1.33 \pm 0.87 \mathrm{~km}^{3}\right)$ were assigned to MIS 5a ( 90-80 ka, [Martinson et al., 1987] on the basis of their interbedded relationship with marine sediments [Conchon, 1985, 1986a, b; Fellin et al., 2005b]. The revised age from OSL dating is 58 $\pm 4 \mathrm{ka}$ [Sømme et al., 2011]. The N3 $\left(1.29 \pm 0.86 \mathrm{~km}^{3}\right)$ deposits were attributed by Fellin et al. [2005b] to MIS 6 (150-130 ka) and to 81-42 ka by OSL dating [Sømme et al., 2011]. It is difficult reconcile the age of the different terraces onshore, this mainly because of hypothesis rather than absolute age dating. We therefore will not use these to constrain the source to sink study as Sømme et al. [2011] did in their manuscript. We consider this record in terms of sediment volumes (3.55 $\mathrm{km}^{3}$ ) as being limited compared to the amount of sediments deposited in the offshore Golo Basin.

\subsection{The offshore perspective}

The offshore Golo Basin is located within the Corsica Trough (Fig. 1A and B). The Golo Basin as referred to in this study corresponds to the area $\sim 1120 \mathrm{~km}^{2}$ outlined in Figure $2 \mathrm{~A}$, containing slope and basin, between the Corsican continental shelf and the Pianosa Ridge. It is bounded to the North by the Corsica Channel and to the South by the transition to the Aleria Basin (Fig. 2B) [Stanley et al., 1980]. Because of the limited extent $\left(\sim 1120 \mathrm{~km}^{2}\right)$ and a high range of depositional environments which include shelf sedimentary wedges, canyons, slope and deepwater depositional elements (channel-levee and terminal lobes), the Golo Basin has been a focus of research for the margin academic community and the petroleum industry [Stanley et al., 1980; Bellaiche et al., 1994; Mauffret et al., 1999; Pascucci et al., 1999; Gervais, 2002, Gervais et al., 2004, 2006a,b; Deptuck et al., 2008; Sømme et al., 2011]. Water depths range from 0 to $\sim 800 \mathrm{~m}$ (Fig. 2A). The three main morphological domains from the shore to the deep basin are the continental shelf (Fig. 2B; slope angle 0 $2.5^{\circ}$ with locally $6-8^{\circ} ; 0-120 \mathrm{~m}$ ), the slope (average slope angle: $3.4^{\circ}$, standard deviation: $2.8^{\circ},>120 \mathrm{~m}$ ), and the basin (av.: $1.3^{\circ}$, s.d.: $\left.1^{\circ}\right)$. These latter two domains are differentiated based on slope values and morpho-sedimentary structures (canyon and channels in white filed features and outline black outlined for lobes, Fig. 2B). Most of the previously recognized deep-water sedimentary bodies (channel-levee and lobes deposit) are located in the basin domain (Fig. 2B) [this study; Gervais, 2002; and Deptuck et al., 2008]. The shelf store 3.55 $\mathrm{km}^{3}$ of sediments considering the sediments above the I seismic marker (Fig. 3A) [Gervais, 2002; and Deptuck et al., 2008], its age will be discussed in the following section of this manuscript [Sømme et al., 2011]. 


\subsection{Climatic perspective}

Continental [e.g. Tzedakis et al., 2003] and deep-sea records [e.g., Cacho et al., 1999; Martrat et al., 2004] indicate that high frequency (millennial) climatic variability (DansgaardOeschger stadials and interstadials, cold and warm phases respectively) prevailed over the Mediterranean Sea during the last glacial period (71-14 ka). Superimposed on the Milankovitch forcing, these rapid coolings (DO stadials) and warmings (DO interstadials) induced a increase/decrease and a lowering/rising of the Mediterranean thermohaline circulation [e.g., Cacho et al., 2000; Toucanne et al., 2012] and of eustatic sea-level [e.g., Sierro et al., 2009], respectively. The most severe climatic conditions were encountered during some peculiar DO stadials, named Heinrich events (HE) [e.g., Cacho et al., 1999; Sanchez Goni et al., 2002], which were times of massive icebergs discharges in the North Atlantic [Hemming, 2004]. Kuhlemann et al. [2008] reveal cold polar air incursions over the central Mediterranean during these periods, and suggest considerable local precipitation in Corsica, as well as over the Apennines, due to the anomalously steep vertical temperature gradients. These conditions led to the development of glaciers in the Mediterranean mountains during the last glacial cycle, especially in the central and northern mountains of Corsica where glaciers up to $14 \mathrm{~km}$ long $\left(\sim 115 \mathrm{~km}^{2}\right)$, extending to altitudes as low as $500 \mathrm{~m}$ above sea level have been identified (Figs 1B and C) [Kuhlemann et al., 2005].

\section{Data set and methods}

\subsection{Seismic reflection}

The eastern margin of Corsica has been imaged by academic reflection seismic surveys since 1990 [Bellaiche et al., 1994; Gervais, 2002, Gervais et al., 2004, 2006a,b; Deptuck et al., 2008]. The seismic data used for the current study are two-dimensional (2D) sub-bottom profiler (SBP) and sparker post-stack, time-migrated reflection seismic data. The SBP and sparker data sets were acquired in 2008 during the SIGOLO survey (Fig. 2C). The data grid has variable $400-800 \mathrm{~m}$ spacing and extends from shelf depth of $\sim 30 \mathrm{~m}$ to the basin floor in $\sim 800 \mathrm{~m}$ of water (Fig. 2A) with a total length of about $2590 \mathrm{~km}$. The frequency content ranges from 2 to $5 \mathrm{kHz}$ and 130 to $750 \mathrm{~Hz}$ for the SBP and sparker seismic data, respectively. For the sparker data, the seismic migration velocities vary spatially based on normal move-out velocity analysis every 250 common depth points. Within the study interval (0-500 ms TWT below seafloor) the interval velocity ranges between 1500 and $1750 \mathrm{~m} . \mathrm{s}^{-1}$. The SBP data have been processed in envelope attribute.

\subsection{Cores}

Extensive databases of cores have been previously described by Gervais [2002]. We have reviewed and reanalyzed 12 Kullenberg-type piston cores collected both in hemipelagic (MDcores) and turbiditic environments (KCO-cores) in the Corsica Trough by the R/V 'Marion Dufresne' (IPEV) and R/V 'L'Europe' (IFREMER), respectively. These 12 coring sites have been selected out of 30 sites, based on penetration and the best spatial-stratigraphic calibration allowing longer term age control and ties to key surfaces of the seismic stratigraphic framework. Coring sites location (Fig. 2A) and details of cores are given in Appendix A Table 1.

Physical properties of the cored sediments were determined by measuring the P-wave velocity and gamma-ray attenuation density every $2 \mathrm{~cm}$ using a 'Geotek Multi Sensor Core Logger' (MSCL). 
Bulk sediment chemistry (relative counting) was measured on whole cores by means of profiling X-ray fluorescence (XRF), using the IFREMER's Avaatech core-scanning XRF. The measurements were done at intervals of $1 \mathrm{~cm}$. Only data for $\mathrm{Ti}$ and $\mathrm{Ca}$ are reported in this study because of their use in assessing clastic mass flux. It is commonly agreed that $\mathrm{Ti}$ should be related to terrigenous-siliciclastic components (clay minerals), while Ca mainly reflects the marine carbonate content (calcite and aragonite) in the sediment [e.g., Richter et al., 2006; Clift et al., 2008; Govin et al., 2012]. Note that the carbonate contents were measured using an automatic calcimeter. The analysis is based on the measurement of the carbon dioxide overpressure generated by the dissolution of the carbonates within $4 \mathrm{~N} \mathrm{HCl}$ acid. Calibration is based on the analysis of a pure carbonate sample every 19 sediment samples. The accuracy of measurements is $\pm 1 \%$.

Powder diffraction (quantitative x-ray fluorescence - XRF) analyses of sediments from core MD01-2472 were conducted at IFREMER. These were used to compute the Chemical Index of Alteration (CIA) [Nesbitt and Young, 1984], which may be used to quantify the degree of source area weathering [e.g. Fedo et al., 1995 and references within]. This index measures the degree of weathering of feldspars relative to unaltered protoliths and is defined as:

$\mathrm{CIA}=\left[\mathrm{Al}_{2} \mathrm{O}_{3} /\left(\mathrm{Al}_{2} \mathrm{O}_{3}+\mathrm{CaO}+\mathrm{Na}_{2} \mathrm{O}+\mathrm{K}_{2} \mathrm{O}\right)\right] \times 100$ (molar proportions) (Eq.1),

where $\mathrm{CaO}^{*}$ represents the $\mathrm{CaO}$ content in the silicate fraction. The high loss on ignition (LOI) valves suggests that we need to correct for the high content of carbonates within the studied sediments, caused by the presence of marine carbonate organisms. Because $\mathrm{CaO}>\mathrm{Na}_{2} \mathrm{O}$, we assumed that the concentration of inorganic $\mathrm{CaO}=\mathrm{Na}_{2} \mathrm{O}$ [Bock et al., 1998] and we then compute the $\mathrm{CIA}^{*}$. $\mathrm{CIA}$ values for unaltered plagioclase and K-feldspars are approximately equal to 50 as in unaltered upper crustal rocks. Values of CIA between $60-80$ are indicative of intermediate weathering [Fedo et al., 1995].

Radiocarbon ages were performed on shells of individual species of planktic foraminifera (preferably Globigerina bulloïdes) hand picked from the bulk sediment. Ages have been corrected for a marine reservoir effect (see details in Appendix 1 - Table 2) and were calibrated to calendar years using the CALIB Rev 6.0.1/Marine09 data set [Stuiver and Reimer, 1993; Reimer et al., 2009]. In addition, stable isotope analyses on sediments from core MD01-2434 and core MD01-2472 were available from previous studies [Gervais, 2002; Toucanne et al., 2012]. These analyses were performed using specimens of benthic foraminifera Uvigerina peregrina and Uvigerina mediterranea from the size fraction $>150 \mu \mathrm{m}$ at Bordeaux University, using an Optima Micromass mass spectrometer. The construction of the chronostratigraphic framework is detailed thereafter.

\subsection{Age models}

The chronostratigraphic framework of cores MD01-2434 and MD01-2472 is based on benthic $\delta^{18} \mathrm{O}$ isotopes, AMS ${ }^{14} \mathrm{C}$ dates and $\mathrm{Ca}$ intensities derived from high-resolution XRF scanning [Toucanne et al., 2012]. The XRF-derived Ca intensities and isotope records have been synchronized with the North Greenland ice core isotope record (GICC05 chronology up to $60 \mathrm{ka}$, NGRIP thereafter) in Greenland [NGRIP-members, 2004; Svensson et al., 2008] because of the close link between Mediterranean climate variations (e.g. DansgaardOeschger oscillations) and the North Atlantic climate [e.g. Cacho et al., 1999; Martrat et al., 2004]. This chronostratigraphic framework reveals that cores MD01-2434 and MD01-2472 extend back to ca $65 \mathrm{k}$ a and ca $130 \mathrm{ka}$, respectively. This strongly challenges Gervais [2002], Gervais et al. [2006] and Sømme et al. [2010] which suggest that core MD01-2434 extends back to $\sim 45 \mathrm{ka}$ only [see Toucanne et al., 2012 for details]. Note that the stratigraphic framework of core MD01-2434 used here shows significant discrepancy with that of Sømme et al. [2010] of ca 2 to $5 \mathrm{ka}$ in the upper part of the core $(0$ to $15 \mathrm{~m})$ and of up to $18 \mathrm{ka}$ in the lower part (15 to $24.9 \mathrm{~m}$ ).

The chronostratigraphic framework of the KCO-cores, which are located in slope-to-basin turbiditic environments, matches the observations from cores MD01-2434 and MD01-2472 
(Fig. 4). In detail, the KCO-to-MD age constraints were performed using correlations of their XRF Ca counts and Ti/Ca relative intensity. Superimposed to the atypical XRF-derived $\mathrm{Ca}$ values of the centimetre-scale sand beds, some high, low and very low $\mathrm{Ca}$ values characterize the MD- and KCO- sediments dating from Marine Isotope Stage (MIS) 1 (14-0 ka), MIS 2 (29-14 ka) and the 26-24 cal ka interval, respectively (Fig. 4). This result reveals the climatic imprint in the hemipelagic sediments interbedded with sand beds [e.g. Jorry et al., 2008; Toucanne et al., 2008]. Coherence between different depositional areas in the slope-basin (i.e., upper slope, channel-levee, lobes) allows us to be confident in the calibration of continuous events observed on the seismic reflection and the local calibration of isolated sedimentary bodies. Previous seismic markers from Gervais (2002) and subsequent studies referring to Horizons I, J, K and L (Fig. 3A) [e.g. Deptuck et al., 2008; Sømme et al., 2011] show no consistency with the new age model calibrated at the scale of the whole Golo Basin [Toucanne et al., 2012].

\subsection{Stratigraphic framework}

These seismic data have been interpreted based on seismic stratigraphic principles [Mitchum et al., 1977; Posamentier and Kolla, 2003] and knowledge of the area derived from previous studies [Gervais, 2002; Gervais et al., 2004, 2006a,b; Deptuck et al., 2008]. Slope to deepwater architectural elements (i.e., canyons, channel-levee and lobes) were recognized in association with regionally-extensive erosion, onlap and downlap surfaces at the base and by extensive high-amplitude continuous reflections with a draping geometry at the top (Fig. 3 ). The different lobes recognized were mapped out and named following the annotations of Deptuck et al. [2008].

The seismic stratigraphic framework used for this study has been built based on four regional continuous seismic reflective events: the seafloor and three sub-bottom (D1-D3) seismic reflections (Figs 3 and 5). These horizons allow us to define three seismic units (S1-S3) and to compute isochore maps (sTWT). Inside these units, individual elements have been recognized. These elements, principally lobes and channel-levee deposits, are defined by top and base horizons, allowing computation of isochore maps (sTWT) for each of these architectural elements in the Golo Basin.

The revised stratigraphic framework is summarized in Figure 6. The three main surfaces, D1, D2 to D3 are dated at 128.9-113ka, 44.9-39.1 ka and 17.1-15.8 ka respectively. These stratigraphic horizons, together with the seafloor, define the three units $\mathrm{S} 1, \mathrm{~S} 2$, and S3. The bulk unit of the studied stratigraphic interval is called S123 (Appendix A - Table 3) (Fig. 6). These units were used to extract the solid sediment thickness maps displayed in Figure 7. The shape of these isopach maps traces the deposition from the Golo catchment and the connection of the onshore fluvial to basin flux of sediment during the last climatic cycle.

\subsection{Quantification steps and uncertainties of solid sediments}

\subsubsection{Time-Depth conversion}

From the seismic stratigraphic framework extracted in the Golo Basin a transformation from time to depth domain has been computed using time-depth information in the study area. To convert the seismically-derived TWT values (below the mudline) into depth we use a timedepth function extracted from the stacking velocities and an interval velocity model compared to the velocity estimates from Multi Sensor Core Logger measurements on cores (Appendix B: Fig. B1-a):

$z=54.2 t^{2}+768.3 t-0.058$ (Eq.2),

where $z$ is the depth $(m)$ of the seismic reflection associated with the horizon or the top/base of an architectural element measured below the seafloor and $t$ is the two-way time-depth of the event below seafloor. $A \pm 5 \%$ uncertainty envelope was used in estimating depth values. The water depth is computed from seafloor reflection TWT values and a seawater velocity of $1500 \mathrm{~m} \cdot \mathrm{s}^{-1}$. 


\subsubsection{Compaction correction}

Compaction (i.e. porosity decay) of recent soft sediment is an important source of uncertainty in quantifying the variation of sedimentary fluxes for different ages. We have estimated values of porosity from sample measurements on cores (MD, Kco; Appendix B: Fig. B1-b). To test the behavior of the sediments (i.e., whether they experience normal or high consolidation rates [Erickson and Jarrard, 1998]; Appendix B: Fig. B2) we have extracted the porosity-velocity data from one set of core data using MSCL measurements. A coherent trend following the normal consolidation curve for shale is observed in most of the Golo Basin core sites, indicating no major influence of early diagenesis (i.e. high consolidation) during burial on the stratigraphic interval used in this study.

The solid sediment thickness estimate follows the methodology of many previous studies [e.g., Métivier et al., 1999; Walford et al., 2005]. Knowing the carbonate content of the different intervals, average carbonate content for unit S1 is $21.2 \pm 5.6 \%$, for unit S2: $19.2 \pm$ $2.9 \%$, and for unit S3: $23.1 \pm 5.5 \%$, we have removed these figure to each interval to obtain 'true' siliciclastic solid sediment. The porosity has been removed from the volume of each isopach to calculate solid sediment rock mass. Porosity, $\Phi$, is assumed to vary exponentially with depth, $z$, according to:

$\Phi(z)=\Phi_{o} e^{-z / k}($ Eq.3)

where $\Phi_{\mathrm{o}}$ is the initial porosity and $\mathrm{k}$ is the porosity decay length.

Using Eq. (2), the solid thickness, Tsol, of a unit is given by:

Tsol $=z_{2}-z_{1}+\Phi_{o} k\left(e^{-z 2 / k}-e^{-z 1 / k}\right)(E q .4)$

where $z_{1}$ is the depth below seabed to the top of the unit and $z_{2}$ is the depth below seabed to the bottom of the unit. Constant values of $\mathrm{k}=10 \mathrm{~km}$ and $\Phi_{o}=0.67$ were determined from the measurements on samples from the Golo Basin (Appendix B: Fig. B1-b).

\subsubsection{Solid sediment flux, sediment yield and denudation estimates}

The solid sediment estimate for the Golo Basin relies on the results of seismic stratigraphic analysis, domain conversions (i.e. time to depth), and the physical properties of sediments from core data. The age model is used to constrain the evolving sedimentary flux $Q s\left(\mathrm{~m}^{3} / \mathrm{yr}\right)$ preserved in the sink area through time. We then compile the available information from the source area to calculate a solid sediment yield. For each stratigraphic unit in the marine basin a corresponding area $\left(A_{n}\right)$ of the source is defined linking the paleo-sea levels and the morpho-bathymetry of the seafloor (i.e., low sea-level results in a bigger drainage area). Yield estimates result from conversion of flux to mass of solid sediment, assuming an average density of $2.7 \mathrm{~g} / \mathrm{cm}^{3}$, and by dividing the mass of each time window by the maximum area of upstream drainage corrected for sea level variation (Fig. 1C, Appendix A - Table 4). Our estimate of paleo-drainage takes into account the extension of the drainage area during sea-level fall, including the potential inclusion of eroded sediments from the pre-deposited sediments on the shelf. Furthermore, this extension of the drainage area allows us to make lower bound estimates of yield, thus making the values conservatives. For unit S1, our estimate of paleo-drainage area extends the drainage area to $\sim 1879 \mathrm{~km}^{2}(55 \%$ increase from present-day area). The paleo-drainage area of unit $\mathrm{S} 2$ at the time of maximum sea-level fall $(120 \mathrm{~m})$ increases to $\sim 2006 \mathrm{~km}^{2}$ (65\% increase to present-day area). For unit S3 the paleodrainage decreased from $\sim 2006 \mathrm{~km}^{2}$ to a minimum area of the present day surface of 1214 $\mathrm{km}^{2}$, during MIS 1 (Fig. 9C). We average the drainage area of the three estimates to a value of $1703 \mathrm{~km}^{2}$ for unit $\mathrm{S} 123$ ( $40 \%$ increase to present day area). 
We use two main data sources (i.e., geomorphologic measurements, SRTM digital elevation model, catchment size, and elevation profiles) and thermochronometers (denudation rate $\varepsilon$ $(\mathrm{mm} / \mathrm{kyr})$ from low-temperature chronometers)) to balance the eroded volume of rocks in the source area with the deposited volume observed in the sink area during the last climatic cycle.

The denudation estimate from solid sediment $\left(\varepsilon_{\mathrm{ss}}\right)$ deposited within the Golo Basin is formulated as:

$\varepsilon_{\mathrm{ss}}=Q s_{n} / A_{n}$ (Eq.4),

with $n$ corresponding to each stratigraphic interval recognized offshore in this study.

The estimated volume of eroded bedrock in the Golo catchment $\left(V_{\varepsilon}\right.$ Golo $)$ using denudation rates from onshore $\left(\varepsilon_{\mathrm{c}}\right)$ is expressed as:

$V_{\varepsilon \text { Golo }}=\varepsilon_{c} \cdot t_{n} \cdot A_{n}($ Eq.5),

with $t_{n}$ corresponding to the duration of each unit,

The values of each parameter and references used for this estimate are provided in Appendix A - Table 4. Density values used for the mass balance were estimated for the offshore sediments from cores, with wet density averaging $1.8 \mathrm{~g} / \mathrm{cm}^{3}$ and dry bulk density of $\sim 2.0 \mathrm{~g} / \mathrm{cm}^{3}$. For most of the Golo watershed bedrock geology (i.e., granite, basalt, and schist) an average density of $2.7 \mathrm{~g} / \mathrm{cm}^{3}$ has been used [Turcotte and Schubert, 2002].

\subsubsection{Estimate of potential errors/uncertainties}

The potential errors or uncertainties in evaluating volumes or masses of sediments include conversion from time (sTWT) into depth $(\mathrm{m})$ (seismic horizons) or depth into time (cores and physical properties) of the subsurface data. Depth conversion is the primary source of uncertainty in the volume estimate and the calibration of stratigraphic surface ages. Each of these aspects has been carefully quantified as envelops with minimum and maximum value estimates. Uncertainties in the first transform (time to depth) are on the order of $\pm 10 \%$. Uncertainties related to porosity removal and density increase with depth could change the overall solid sediment thickness by $5-10 \%$. An uncertainty of $5-15 \%$ for the overall basin, as well as for the detailed stratigraphy and architecture, has been geographically and vertically assessed by different coherent calibrated techniques $\left(\delta^{18} \mathrm{O}\right.$ isotopes, AMS ${ }^{14} \mathrm{C}$ and NGRIP calibration of $\mathrm{Ca}$ XRF signal) and multiple points of controls. All these uncertainties were integrated in the computation of the volume estimates per unit time of the sediments deposited in the Golo Basin. The average denudation rate has been computed considering the maximum extent of the paleocatchment in relation to the maximum relative sea-level variations for each unit. This approach makes our estimate of the basin-wide denudation conservative.

\section{Results}

\subsection{Solid sediments evolution over the last $130 \mathrm{ka}$}

The deep basin was fed by various point sources located at the shelf break; from North to South the sediments were delivered through the Saint Dominiano Canyon (St Do), Biguglia Canyon (Bi), North Golo Canyon (NGC), Pineto gully (Pi), and South Golo Canyon (SGC) and Fium Alto gully (Fi) (Fig. 7A). At the scale of the last climatic cycle (Fig. 7A), the isopach 
map shows three main depocenters essentially related to the NGC and SGC. The maximum total thickness for unit S123 is $48.9 \mathrm{~m}$. Minimum values (>10 m, Fig. 7A) are found in the upper slope of the margin south of the NGC. If we consider the relative volume of sediments by domains (basin and slope, Fig. 2B), the basin represents over $75 \%$ of the total volume of sediment within the studied intervals (Fig. 8). Adding the estimated figure for the shelf depositional units of $3.55 \mathrm{~km}^{3}$ (i.e. without porosity correction) [Sømme et al. 2011], the basin and slope estimated here will still represent $87 \%$ of the sediments deposited in the whole offshore Golo Basin.

Within unit S1 $(122.5 \pm 9.4$ to $\sim 40.9 \pm 3 \mathrm{ka}$, Fig. 3) the main depocenters are associated with lobes A1, B2, A2, B3a,b and A3 (Fig. 7B). The maximum thickness of $41.5 \mathrm{~m}$ occurs in lobe B2 associated with the NGC canyon. During deposition of this unit, both North and South Golo canyons were active. Because no age calibration of the lobes within unit S1 is available except for the lobe B2, we have no detail on the sedimentation rates related to these elements (Fig. 6). The main onshore supply must have been brought to the basin by the Golo drainage and NGC and SGC, with only minor contribution from the coastal drainages such as Saint Dominiano and Fium Alto (Fig. 7B). The solid sediment volume of unit S1 is $10.67 \pm$ $2.61 \mathrm{~km}^{3}$ (Appendix A - Table 3).

Unit S2 $(40.9 \pm 3$ to $\sim 16.5 \pm 0.7 \mathrm{ka}$, Fig. 3$)$ is the stratigraphic interval where the depositional elements studied have been age calibrated in greatest detail (Fig. 7C, Appendix A - Table 3). The lobes $C 1, B s$ and $C 2$ are related to a northern point source while the lobes C3, D3, $\mathrm{E} 3$, and Fi would be related to a southern point source (Figs 6 and $7 \mathrm{C}$ ). This interval shows a maximum thickness of $27 \mathrm{~m}$ (Fig. 7C) and a solid sediment volume of $7.77 \pm 1.89 \mathrm{~km}^{3}$. During deposition of this interval the sedimentation was focused in the basin, with a switch of sediment feed from the North to South Golo canyon (Fig. 6). The cumulative volume of the NG and SG lobe elements are of the same order, $1.09 \pm 0.05 \mathrm{~km}^{3}$ and $1.11 \pm 0.1 \mathrm{~km}^{3}$ respectively (Appendix $A-$ Table 3 ).

Unit S3 ( 16.5 \pm 0.7 to $0 \mathrm{ka}$, Fig. 3) contains the three most recent lobes deposited in the northern part of the proximal margin slope: Biguglia (Bi), North Golo (NG) and Pineto (Pi) lobes (Fig. 7D). No evidence of depositional elements were found South of the Pineto lobe within this unit. Outside this NW area the basin has experienced continuous deposition of muddy sediments (Fig. 5). The maximum thickness for this interval is $12.9 \mathrm{~m}$, and the solid sediment volume of unit $S 3$ is $1.48 \pm 0.43 \mathrm{~km}^{3}$, including $0.19 \pm 0.01 \mathrm{~km}^{3}$ for the three lobes (Appendix A - Table 3). The three northernmost canyons and gullies are the main sediment point sources. These sedimentary bodies (proximal isolated lobes, sensu Deptuck et al. [2008]) were recorded near the slope-basin boundary and were inferred to have been deposited during the last sea-level rise in response to transgressive reworking of lowstand deposits on the outer shelf [Deptuck et al., 2008].

\subsection{Sediment flux and yield to the Golo Basin}

The evolution of the sedimentary record in the Golo Basin since 130 ka shows distinct patterns within three units associated with the connection of the Golo drainage with the canyon heads ( 120-140 m present day water depth). We analyze these variations in term of the flux of sediments and yield delivered from the source to the preserved record (sink).

\subsubsection{Last 50 ka record of sediment flux}

We focus first on the solid sediment flux in the Golo Basin during the last 50 ka (Fig. 9A). The lowest value of solid sediment flux (Qs, i.e. minimum volume estimation and longest duration) of the three identified units is observed during unit S3 with $0.062 \mathrm{~km}^{3} / \mathrm{kyr}$. Unit S2 records the highest minimum flux of solid sediment of $0.202 \mathrm{~km}^{3} / \mathrm{kyr}$. Unit $\mathrm{S} 1$ shows intermediate minimum values of $0.089 \mathrm{~km}^{3} / \mathrm{kyr}$ (Fig. 9A). The long-term minimum flux as for unit $\mathrm{S} 123$ is $0.116 \mathrm{~km}^{3} / \mathrm{kyr}$. 
The geometry of the Corsican Trough (Fig. 5) and evidence of confined depocenters within the studied intervals (Fig. 7A) show that most of the sediments come from the Golo and coastal rivers (Fium Alto and Benvico, Fig. 2). The minimum figures of flux estimated above represent the lower bound of the river sediment load feeding the basin (Fig. 9B). In the setting of the 50-15 ka period, the accommodation space available on the shelf for sedimentation was low (Figs $1 \mathrm{C}$ and $9 \mathrm{C}$ ). The direct evidence of reduced shelf area during the lowstand when sea level is 60 or $120 \mathrm{~m}$ lower (MIS 4 to MIS 2) supports the hypothesis that the volumes (Fig. 8) deposited in the Golo Basin at this time represent the most reliable signal of the sedimentary flux from the onshore erosion part of the system.

\subsubsection{Last 130 ka record of sediment yield}

Figure 9B presents the solid sediment yield for the last $130 \mathrm{ka}$. The resulting integrated longterm yield to the basin corresponds to the estimate of unit S123 (duration: 129.8-113.1 kyr). Values range from $1.56 \times 10^{2}-2.38 \times 10^{2} \mathrm{t} / \mathrm{km}^{2} / \mathrm{yr}$. Sequentially, unit $\mathrm{S} 1$ (duration: 90.7-68.1 $\mathrm{kyr}$ ) yield values are $9.78 \times 10^{1}-2.08 \times 10^{2} \mathrm{t} / \mathrm{km}^{2} / \mathrm{yr}$, increasing during unit S2 (duration: $29.1-22.0 \mathrm{kyr}$ ) to $2.02 \times 10^{2}-4.38 \times 10^{2} \mathrm{t} / \mathrm{km}^{2} / \mathrm{yr}$, then decreasing during unit S3 (duration: $17.1-15.8 \mathrm{kyr}$ ) to $6.15 \times 10^{1}-1.98 \times 10^{2} \mathrm{t} / \mathrm{km}^{2} / \mathrm{yr}$ (Fig. 9B).

\subsection{Mass balance of the Golo sink and source}

We investigate the published results on denudation rates from the Golo drainage catchment (Figs $1 \mathrm{~B}$ and $\mathrm{C}$ ) and test whether there is a balance with the estimate of the potential eroded rocks from the onshore catchments by integrating in time and drainage equivalent to the three offshore preserved solid sediment mass (Fig. 10A).

For the onshore estimate of eroded rock mass, we have compiled published results of short term weathering rates [Kuhlemann et al., 2009], incision of bedrock by rivers [Fellin et al., 2005b; Sømme et al., 2011] and thermochronometer long-term studies (Apatite Fission Track and Apatite (U-Th)/He) analyzed in Corsica [e.g., Fellin et al., 2005b; Danišík et al., 2007]. Kuhlemann et al. [2009] considered that there was a good agreement between the minimum values from long and short-term measurements in the record of the different studied areas onshore Corsica, including the Golo catchment. Sømme et al. [2011] found 1-2 orders of magnitude difference between the trunk river incision rates compared to the cosmogenic denudation. Because the denudation estimate onshore integrates different local processes we assume that these tools can be used to estimate catchment-wide minimum denudation rates.

Figure 10A summarizes the results of the mass estimation of onshore and offshore solid sediments, together with the uncertainties related to the duration, and minimum-maximum denudation (Appendix A - Table 4). For these denudation rates of 9-20 mm/kyr were applied to each time window with the exception of the post-glacial unit S3 which has a maximum value of $140 \mathrm{~mm} / \mathrm{kyr}$ [Kuhlemann et al., 2009]. Among the three units from our study, only unit S3 can be balanced with the estimated eroded rock mass from the Golo catchment, for average values of denudation of $\sim 75 \mathrm{~mm} / \mathrm{kyr}$. Units $\mathrm{S} 1$ and $\mathrm{S} 2$ shows ratios of onshore (drainage) offshore (sedimentary basin) mass of 3.7 to 7.3 respectively, meaning that there is much more sediment than known onshore erosion (Appendix A - Table 4). This mis-match of preserved sediments and eroded bedrock raises the question of whether the denudation estimated onshore is suitable for calculation of potential basin-wide erosion. The estimate is a maximum value of total denudation.

To test if the paleo-Golo source to sink system is a low or highly efficient sediment routing system [Milliman and Syvitski, 1992], we compare the sediment yield values obtained in this 
study with regional estimates of drainage area-yield relationship from rivers within the Mediterranean basins of mountainous, Alpine, upland and lowland classifications based on maximum basin elevation [Milliman and Syvitski, 1992], and using the tectonic framework developed by Hovius [1998]. The present day Golo River (anthropogenic influenced catchment) sediment load shows sediment yield values of $\sim 585 \mathrm{t} / \mathrm{km}^{2} / \mathrm{yr}$ (Fig. 10B, sediment load from the Golo River converted to yield, value in Appendix A - Table 5 from Sømme et al. [2009]). Figure 10B, shows the drainage area-yield relationship of the three units of the paleo-Golo River. Units S1 (MIS 5 to MIS 3 ) and S3 (MIS 1) lie within the lower bound of the present day rivers located in the Mediterranean Sea basin, from lowland to upland types of catchments and within the thermal extension type of tectonic framework. Unit S2 stands out of this setting and lies between upland to high mountainous-alpine type settings, and towards the contraction tectonic end member (Fig. 10B). Relatively to the present day Golo River sediment load, the sediment yield during deposition of units S1 and S3 are lower by two to over five times. Sediment yield only equals or surpasses the present day value by two to three times during deposition of unit S2 (Fig. 10B).

We compare the values computed from the sediment budget with a compilation of regional denudation studies Corsica [Fellin et al., 2005b; Kuhlemann et al., 2009] (Appendix A Table 4). Values for the three areas derived from AFT/AHe data range from 25 to 220 $\mathrm{mm} / \mathrm{kyr}$ over the last 7 to $3 \mathrm{Ma}$. Regarding the denudation rates estimated from cosmogenic ${ }^{10} \mathrm{Be}$ data, the values for the last $\sim 100 \mathrm{ka}$ averaged from 9 to $140 \mathrm{~mm} / \mathrm{kyr}$. The observed incision rates based on terrace analysis in the Golo catchment show values of 160-475 $\mathrm{mm} / \mathrm{kyr}$ [Fellin et al., 2005b]. Using high resolution GPS measurements and terraces chronology, Sømme et al. [2011] estimated rate of incision for the Golo River of 190-420 $\mathrm{mm} / \mathrm{kyr}$, with varying values from the different tectonic domains from the Variscan and the Alpine Corsica.

In the previous section we demonstrated that only unit S3 provides a match between the mass balance of offshore solid sediments and the eroded rock onshore. The mis-match for units S2 and S1 is thought to be related to the potential underestimation of the onshore erosion through the use of denudation proxies from previous published works of low definition. We now quantify the solid sediment preserved in the Golo Basin to reconstruct the potential range of denudation values by inverting this sedimentary signal into denudation values. For this we simply divide the volume of solid sediment of each unit by the maximum drainage area and divide it by the duration of the corresponding time (filled circle in Figure 10C). The uncertainties for each unit (i.e., minimum-maximum values) are plotted and outlined by gray boxes in Figure $10 \mathrm{C}$. The minimum, average and maximum values of denudation from onshore studies are also plotted for reference (open circles in Fig. 10C). A $5-12 \%$ uncertainty is related to volume variation (minimum-maximum) for a constant time window. The resulting analysis from the solid sediment analysis in the basin shows that values of potential denudation exceed the onshore-published denudation measurements by an order of magnitude. The background estimate from unit S123 shows values from 47-104 $\mathrm{mm} / \mathrm{ky}$, again 5-10 times the long-term minimum estimate from AFT, or short term from cosmogenic studies. The highest potential denudation rate from solid sediment signal is again recorded for unit S2, values range from 101 to $219 \mathrm{~mm} / \mathrm{kyr}$.

\subsection{Chemical index of alteration}

The sedimentation in the basin should illustrate the chemical denudation and the physical denudation. We here try to analyze the sedimentary signal as a information of chemical alteration using geochemical proxies. For this we have computed the chemical index of alteration $\left(\mathrm{CIA}^{*}\right)$ for the sediments in core MD01-2472 (green curve and rectangles, Fig. $11 \mathrm{G})$. We overlay on the $\mathrm{CIA}^{*}$ a high-resolution XRF Ti/Ca ratio (light gray) as a source flux proxy. The $\mathrm{CIA}^{*}$ range values (62-70 $\mathrm{CIA}^{*}$ ) observed in core MD01-2472 are indicative of moderate weathered rocks at the source [Fedo et al., 1995]. Increases of $\mathrm{ClA}^{*}$ during the 
glacial period (71-14 ka) correlate with the overall increase in XRF Ti/Ca ratio. This suggests a higher alteration with flux of sediments in the Golo Catchment during glacials. During interglacial periods when there were lower fluxes of sediments to the basin, the peak in $\mathrm{CIA}^{*}$ values can be interpreted as an indication of alteration of rocks due to stronger rain falls [Kallel et al., 2000].

\section{Discussion}

The Golo Basin allows the potential links and scales of the sediment routing system in East Corsica to be strongly constrained because in this region we have access to a particularly complete set of onshore and offshore data. We now discuss reasons for the potential bias from adjacent source to sink systems (e.g. the Tavignano River located south, Fig. 3), climatically inferred influences, and need to further calibrate the missing information in the catchment (source), as well as in the basin (sink).

\subsection{Sediment routing system}

The main point raised by this study is that the signal from the source (denudation, weathering) can only be studied if convolved with a well-known signal, such as the time-clock preserved in the sink. We acknowledge that much of the transition domain and its buffering role (fluvial system and platform) is underestimated in the present study, because of the poor information and low volumes of sediments in this setting, compared with the slope and basin area of the Golo River. The fine grained portion sourced from the Golo catchment, represents the biggest part of the signal in the basin, which make very low the preservation potential in the Golo catchment (i.e., even within the coastal domain). Only tracing techniques applied to the present-day system can provide information on the time scale of seasonal transfer of the source materials, to the sink, assuming we can correct for anthropogenic effects. The climatic and topographic setting of Corsica (Fig. 1B) represents a setting in which flushing of weathered material can transfer sediment seasonally to the sink (offshore in this case) and minimum storage occurs in the source.

Kettner and Syvitski [2009] have simulated (numerical model: HydroTrend) the evolution of three Mediterranean watershed/rivers (Têt, Rhône and Pô) over the last 21 kyr and found a reduction in flux of sediments between the late glacial flux and the observed Holocene period (factor from 2.4 to 3.5). The same trend is observed in the Golo slope and basin sediment record (Fig. 9B). Counterwise the present day value of the Golo river discharge is 2.9 to 8.4 times higher than the Holocene estimate, which is in contradiction with the reduced sediment flux observed over the last decades on the three rivers studied by Kettner and Syvitski [2009]. This observation strongly questions the role of an anthropogenic effect in the present day denudation of the Golo Catchment.

\subsection{Oceanographic influence on mass balance}

The long shore transport of sediments has been identified along continental margins as a potential bias in sediment dispersal from the shelf to the basin [Flemming, 1981; Stanley, 1989; Boyd et al., 2008; Guillocheau et al., 2012]. The influence of the Tavignano River (Fig. $1 \mathrm{C})$ as a southern potential source of sediment to the study area cannot be ruled out as a contributor to the Golo Basin sedimentary pile. The Tavignano River could have supplied fine particles that were transported as suspended load, mainly by the S-N surface current as well as by the Levantine Intermediate Water current at a present day water depth of 200 to $600 \mathrm{~m}$ [Toucanne et al., 2012]. This current sweeps the slope and basin with a mean flow velocity of $17 \mathrm{~cm} \cdot \mathrm{s}^{-1}$ [Astraldi and Gasparini, 1992]. The Golo Basin could gain sediment through these bottom or surface currents, but it could also lose sediments by transfer to the North towards the Ligurian Sea (Figs 2A and B). To the North of the study area Roveri [2002] described a drift complex on the edge of the Elba Ridge, that may have accumulated since 
the middle Pliocene. Further evidence for accretion of these fine-grained drift sediments since the LGM and no potential input from the Italian continental shelf suggests that sediment loss by current reworking should be considered in the mass balance. To test the potential influence of lateral S-N migration of fine sediments volume from other basins, a complete, equivalent study would need to be performed to the North (Cap Corse and Ligurian Sea) and to the South (Tavignano Basin and northern Tyrrhenian Sea) of the Golo survey used for this study (Fig. 1B). Solid sediment isopach maps with detailed analysis of potential drift deposits and geochemical provenance study analysis of the different catchment contribution would enable the contribution of currents to lateral migration of fine-grained sediments at the scale of $>100 \mathrm{~km}$ to be quantified. Nevertheless, we think that the volume estimate of solid sediment makes the analysis of flux from the onshore sediments valid, even after considering any potential role played by intermittent activity of currents in the area.

\subsection{Climatically-induced change in denudation during the last climatic cycle $(130 \mathrm{kyr})$}

Climatic constraints in the western Mediterranean basin suggest fluctuating atmospheric conditions over the last climatic cycle, changing from cool/dry to warm/temperate conditions (Fig. 11A), as shown via biomes analysis in Italy [Allen et al., 1999] and sea-surface temperature reconstructions from the Alboran and Tyrrhenian Seas [Paterne et al., 1999; Martrat et al., 2004, see Fig. 11C]. The latter suggest variations of paleo-temperatures ranging from 7 to $25^{\circ} \mathrm{C}$, with oscillations related to glacial and interglacial periods. Pollen assemblages from Lake Ionnina (Greece) (Fig. 11B) have also highlighted the changes in vegetation in relation with these atmospheric variations [Tzedakis et al., 2002].

The terrigeneous mass accumulation rate in core MD01-2472 (Fig. 11F) shows a high frequency variation of the fluxes transmitted from the source to the sink over the last climatic cycle. The highest rates are observed during the glacial period (ca 60 to $20 \mathrm{ka}$ ). In relation with the climatic variations in the Mediterranean area over the last $130 \mathrm{kyr}$, we suggest that increases in sedimentation rates in the Golo Basin are related to glacial events (physical weathering and denudation) within the Golo catchment, whereas lower rates of sedimentation and higher chemical alteration $\left(\mathrm{ClA}^{*}\right)$ are related to interglacial periods, with higher precipitations over the elevated center of the island of Corsica. Hinderer [2001] demonstrated that the denudation of the Alps was faster during glacial periods, while erosion and sediment production was lower during interglacial periods (Fig. 11D). The Golo Basin, like the Alkyonides Basin in Greece [Collier et al., 2000] for the same time window, shows an increase in preserved deposits in the offshore basins during glacial periods (Fig. 11E). This faster transfer of sourced sediments is coherent with the high sediment production and export rates during glacial periods, as well as the advance and retreat of glaciers in the upstream catchment [Kuhlemann et al., 2008]. Preliminary results on source analysis $\varepsilon \mathrm{Nd}$ isotopic signature on the core MD01-2472 [personnal communication: F. Haurine] confirm this result showing evidence of a higher contribution of Variscan Corsica basement during glacial periods than during interglacial periods. In detail, maximum glacier expansion in Variscan Corsica (Fig. 1C) occurred during the global LGM, precisely after ca 28 ka [Kuhlemann et al., 2005, 2008]. At that time glaciers in Central Apennines, Italy, also reached their maximum extension (ca $26 \mathrm{ka}$ ) followed by a rapid retreat between ca 26 and $21 \mathrm{ka}$ [Giraudi \& Frezzotti, 1997]. High values of sediment flux and CIA* at site MD01-2472 between ca 40 and 20 ka likely highlight this pattern of glaciers fluctuations in the Central Mediterranean area. Similar results by modeling of the Pô source to sink system shows that glacial processes are a dominant factor controlling the sediment flux to the ocean [Kettner and Syvitski, 2008].

\subsection{Implication for study of source to sink systems}

Most of the source to sink studies are challenged by the lack of constrains/data in one or another area. Far from answering to yet unsolved questions regarding the Earth surface processes that most of the community is challenging for source to sink studies (mostly by 
models), we discuss potential aspect of data imbrications. First of all, when sedimentary basin are well constrained, volumes of solid sediments and detailed age models could help the communities working on relief denudation to frame the potential envelope of total denudation into their forward or inverse modeling of thermochronometers. The numerical models of catchment erosion should approach the quantification of the processes and resulting volumes of materials removed from the source as a next step towards the understanding of basin fill.

In the setting of mountains and foreland basins, the vertical/lateral evolution of the preserved erosion is lacking of details [Métivier et al., 1999; Hinderer et al., 2001; Clevis et al., 2004; Barns and Pelletier, 2006; Barnes and Heins, 2009] and a continuously calibrated natural laboratory is still yet to be analyzed. In the setting of craton type source area, where the quantification of the vertical denudation is a challenge, the sedimentary signal has a key role to play in identifying the missing record in the source area [e.g. Guillocheau, et al., 2012]. Challenge on the scaling of the processes and calibration of factors affecting the earth surface will obviously reach an agreement between the source and sink communities.

\section{Conclusions}

We draw the following conclusions from this study:

1. The present study shows a coherent image of a simple source-to-sink system within the well constrained climatic cycle in the Mediterranean Sea;

2. A complete analysis of the various data from the offshore sink, i.e. the Golo Basin and the source regions in the Golo catchment allows us to constrain the preserved signal within the sedimentary section to be compared to observations in the source area;

3. The present study represents a significant advance in terms of age calibrated stratigraphic surfaces and depositional elements, compared to previous works;

4. The high rates of sediment fluxes to the basin correlate with emplacement of a complete sedimentary depositional profile that is now preserved from the continental shelf to the distal lobes in the deep basin. This dominant fine-grained sedimentation occurred during glacial periods in the source area due to glacier oscillations, and enhanced denudation, in the Golo catchment. Interglacial periods are associated with a lower flux of sediment and higher chemical alteration linked with higher precipitation over Corsica;

5. Mis-matched mass balance between preserved sediments and the estimates of produced sediments from rocks in the catchment calculated from denudation proxies (i.e., thermochronology, cosmogenic isotopic studies) leads us to re-evaluate the average denudation of the Golo catchment as being of an higher order of magnitude at least since $130 \mathrm{ka}$ compared to long-term average. Catchment-wide denudation calculated from solid sediments deposited in the sink is $47-219 \mathrm{~mm} / \mathrm{kyr}$ (during the last $130 \mathrm{kyr}$ ). This is higher than the low estimate $(9-140 \mathrm{~mm} / \mathrm{kyr}$ ) from paleosurfaces ablation in the proximal part of the source and lower than the distal narrow incised channel of the Golo River (160-475 mm/kyr);

Further analysis of the points raised in this paper could lead to better definition of sediment transport in this source to sink system and could lead to important advances in our understanding of the time scales of transfer in Earth surface processes.

\section{Acknowledgments}

We would like to thank all the people and crew members of the R/V Marion Dufresne II ("MD123-Geosciences 1" and "MD124-Geosciences 2" cruises), R/V L'Europe ("Corfan 1" cruise) and R/V Le Suroît ("Corfan 2" and "Sigolo cruise) that cruised off the Golo Basin. The Golo Program community, Ifremer and partners ExxonMobil and Total are thanked for their collaboration, allowing this work to be published. S. Ker, B. Marsset and Y. Le Gall (Ifremer) are thanked for discussion and knowledge sharing on the geophysical data and tools used 
for this study. Thanks to A. Normand (Ifremer) for seafloor data bathymetry processing. G.C. carried this work during a year contract at Ifremer (Brest) and wrote this paper during an English summer in Manchester University - School of Earth, Atmospheric and Environmental Sciences, within the Basin Studies and Petroleum Geoscience group as a research visitor. GC would like to thanks P. Clift (Louisiana State University) for reviewing an earlier version of this manuscript. This paper is dedicated to Bruno Savoye who initiated the Golo Program and gather communities from all around the world to study this sediment routing system. Tor Sømme, Serge Berne and an anonymous reviewer helped to improve the manuscript. Thanks to Peter van Beek for editorial support.

\section{References}

ALLEN, J.R.M., BRANDT, U., BRAUER, A., HUBBERTEN, H.-W., HUNTLEY, B., KELLER, J., KRAML, M., MACKENSEN, A., MINGRAM, J., NEGENDANK, J.F.W., NOWACZYK, N.R., OBERHÄNSLI, H., WATTS, W.A., WULF, S. \& ZOLITSCHKA, B. (1999) Rapid environmental changes in southern Europe during the last glacial period, Nature, 400, 740743, doi: $10.1038 / 23432$

ALLEN, P.A. (1997) Earth Surface Processes, Blackwell, London. 404p.

ALLEN, P.A. (2005) Striking a chord, Nature, 434, 961, doi: 10.1038/434961a

ASTRALDI, M., \& GASPARINI, G. (1992) The Seasonal Characteristics of the Circulation in the North Mediterranean Basin and Their Relationship With the Atmospheric-Climatic Conditions, Journal of Geophysical Research, 97(C6), 9531-9540.

BARNES, J.B. \& PELLETIER, J.D. (2006) Latitudinal Variation of Denudation in the Evolution of the Bolivian Andes, American Journal of Science, 306(1), 1-31, doi: 10.2475/ajs.306.1.1

BARNES, J.B. \& HEINS, W.A. (2009) Plio-Quaternary sediment budget between thrust belt erosion and foreland deposition in the central Andes, southern Bolivia, Basin Research, 21(1), 91-109, doi: 10.1111/j.1365-2117.2008.00372.x

BELLAICHE, G., DROZ, L., GAULLIER, V. \& PAUTOT, G. (1994) Small submarine fans on the eastern margin of Corsica: Sedimentary significance and tectonic implications, Marine Geology, 117(1-4), 177-185, doi: 10.1016/0025-3227(94)90013-2.

BOCK, B., MCLENNAN, S.M. \& HANSON, G.N. (1998) Geochemistry and provenance of the Middle Ordovician Austin Glen Member (Normanskill Formation) and the Taconian Orogeny in New England, Sedimentology, 45(4), 635-655, doi: 10.1046/j.1365-3091.1998.00168.x

BOYD, R., RUMING, K., GOODWIN, I., SANDSTROM, M. \& SCHRÖDER-ADAMS, C. (2008) Highstand transport of coastal sand to the deep ocean: A case study from Fraser Island, southeast Australia, Geology, 36, 15-18, doi: 10.1130/G24211A.1

CACHO, I., GRIMALT, J.O., PELEJERO, C., CANALS, M., SIERRO, F.J., FLORES, J. A. \& SHACKLETON, N. (1999) Dansgaard-Oeschger and Heinrich event imprints in Alboran Sea paleotemperatures, Paleoceanography, 14(6), 698-705.

CACHO, I., GRIMALT, J.O., SIERRO, F.J., SHACKLETON, N. \& CANALS, M. (2000) Evidence for enhanced Mediterranean thermohaline circulation during rapid climatic coolings, Earth and Planetary Science Letters, 183(3-4), 417-429.

CAVAZZA, W., ZATTIN, M., VENTURA, B. \& ZUFFA, G.G. (2001) Apatite fission-track analysis of Neogene exhumation in northern Corsica (France), Terra Nova, 13(1), 51-57, doi: 10.1046/j.1365-3121.2001.00316.x. 
CLEVIS, Q., DE JAGER, G., NIJMAN, W. \& DE BOER, P.L. (2004) Stratigraphic signatures of translation of thrust-sheet top basins over low-angle detachment faults, Basin Research, 16(2) 145-163, doi: 10.1046/j.1365-2117.2003.00226.x

CLIFT, P.D., HODGES, K. V., HESLOP, D., HANNIGAN, R., VAN LONG, H. \& CALVĖS, G. (2008) Correlation of Himalayan exhumation rates and Asian monsoon intensity, Nature Geoscience, 1, 875 - 880, doi: 10.1038/ngeo351

COCCO, M., SELVAGGI, G., DI BONA, M. \& BASILI, A. (1993) Recent seismic activity and earthquake occurrence along the Apennines. In: Recent evolution and seismicity of the Mediterranean region (Ed. by E. Boschi, et al.), Kluwer Academic Publishers, Dordrecht, Netherlands, pp. 259-312.

COLLIER, R.E.L., LEEDER, M.K., TROUT, M., FERENTINOS, G., L YBERIS, E. \& PAPATHEODOROU, G. (2000) High sediment yields and cool, wet winters: Test of last glacial paleoclimates in the northern Mediterranean, Geology, 28(11), 999-1002, doi: 10.1130/0091-7613(2000)28<999:HSYACW>2.0.CO;2

CONCHON, O. (1977) Néotectonique en C orse orientale d'après l'étude des formations quaternaries: Comparaison entre la Marana et la plaine d'Aleria, Bulletin de la Société Géologique de France, 19, 631-639.

CONCHON, O. (1978) Quaternary studies in Corsica (France), Quaternary Research, 9(1), 41-53.

CONCHON, O. (1985) Le Quaternaire littoral de Corse: Nouvelles données, Bull. Assoc. Fr. Quat., 1, 13-20.

CONCHON, O. (1986a) Quaternary glaciations in Corsica, Quaternary Science Reviews, 5, 429-432, doi: 10.1016/0277-3791(86)90208-8.

CONCHON, O. (1986b) Corrélations entre les formations glaciaires, fluviatiles et marines de Corse et les sédiments sous-marins de Méditerranée occidentale au Pléistocène supérieur, Rev. Geol. Dyn. Geogr. Phys., 27, 85-93.

DANIŠÍK, M., KUHLEMANN, J., DUNKL, I., SZÉKELY, B. \& FRISCH, W. (2007) Burial and exhumation of Corsica (France) in the light of fission track data, Tectonics, 26, TC1001, doi: 10.1029/2005TC001938.

DAVIES, T.A., HAY, W.W., SOUTHAM, J.R. \& WORSLEY, T.R. (1977) Estimates of Cenozoic Oceanic Sedimentation Rates, Science, 197, 53-55.

DE MARTONNE, E. (1910) L'érosion glaciaire et la formation des vallées alpines, Annales de Géographie, 19(106), 289-317. doi : 10.3406/geo.1910.7632

DEPTUCK, M.E., PIPER, D.J.W., SAVOYE, B. \& GERVAIS, A. (2008) Dimensions and architecture of late Pleistocene submarine lobes off the northern margin of East Corsica, Sedimentology, 55(4), 869-898, doi: 10.1111/j.1365-3091.2007.00926.x.

ERICKSON, S.N., \& JARRARD, R.D. (1998) Velocity-porosity relationships for watersaturated siliciclastic sediments, Journal of Geophysical Research, 103(B12), 30385-30406.

FEDO, C.M., NESBITT, H.W. \& YOUNG, G.M. (1995) Unraveling the effects of potassium metasomatism in sedimentary rocks and paleosols, with implications for paleoweathering conditions and provenance, Geology, 23(10), 921-924, doi: 10.1130/00917613(1995)023<0921:UTEOPM>2.3.CO;2 
FELLIN, M.G., PICOTTI, V. \& Z ATTIN, M. (2005a) Neogene to Quaternary rifting and inversion in Corsica: Retreat and collision in the western Mediterranean, Tectonics, 24, TC1011, doi: 10.1029/2003TC001613.

FELLIN, M.G., ZATTIN, M., PICOTTI, V., REINERS, P.W. \& NICOLESCU, S. (2005b) Relief evolution in northern Corsica (western Mediterranean): Constraints on uplift and erosion on long-term and short-term timescales, Journal of Geophysical Research, 110, F01016, doi: 10.1029/2004JF000167.

FELLIN, M.G., VANCE, J.A., GARVER, J.I. \& ZATTIN, M. (2006) The thermal evolution of Corsica as recorded by zircon fission-tracks, Tectonophysics, 421(3-4), 299-317, doi: 10.1016/j.tecto.2006.05.001.

FLEMMING, B.W. (1981) Factors controlling shelf sediment dispersal along the southeast African continental margin, Marine Geology, 42(1-4), 259-277, doi: 10.1016/00253227(81)90166-3.

FLORINETH, D. \& SCHLUCHTER, C. (1998) Reconstructing the Last Glacial Maximum (LGM) ice surface geometry and flowlines in the central Swiss Alps, Eclogae Geologicae Helvetiae, 91(3), 391-407

GERVAIS, A. (2002) Analyse multi-échelles de la morphologie, de la géométrie et de l'architecture d'un système turbiditique sableux profond (système du Golo, marge est Corse, mer Méditerranée), Unpublished PhD thesis, University Bordeaux 1, n²621, 285 pp. http://www.asf.epoc.u-bordeaux1.fr/theses/Manuscrits/GERVAIS 2002.pdf.

GERVAIS, A., SAVOYE, B., MULDER, T. \& GONTHIER, E. (2006a) Sandy modern turbidite lobes: A new insight from high resolution seismic data, Marine and Petroleum Geology, 23(4), 485-502, doi: 10.1016/j.marpetgeo.2005.10.006.

GERVAIS, A., MULDER, T., SAVOYE, B. \& GONTHIER, E. (2006b) Sediment distribution and evolution of sedimentary processes in a small sandy turbidite system (Golo system, Mediterranean Sea): implications for various geometries based on core framework, GeoMarine Letters, 26(6), 373-395, doi:10.1007/s00367-006-0045-z.

GERVAIS, A., SAVOYE, B., PIPER, D.J.W., MULDER, T., CREMER, M. \& PICHEVIN, L. (2004) Present morphology and depositional architecture of a sandy confined submarine system: the Golo turbidite system (eastern margin of Corsica), Geological Society, London, Special Publications, 222, 59-89, doi: 10.1144/GSL.SP.2004.222.01.05.

GIRAUDI, C. \& FREZZOTTI, M. (1997) Late Pleistocene Glacial Events in the Central Apennines, Italy, Quaternary Research, 48(3), 280-290,doi: 10.1006/qres.1997.1928.

GOVIN, A., HOLZWARTH, U., HESLOP, D., FORD KEELING, L., ZABEL, M., MULITZA, S., COLLINS, J.A. \& CHIESSI, C.M. (2012) Distribution of major elements in Atlantic surface sediments $\left(36^{\circ} \mathrm{N}-49^{\circ} \mathrm{S}\right)$ : Imprint of terrigenous input and continental weathering, Geochem. Geophys. Geosyst., 13, Q01013, doi:10.1029/2011GC003785.

GUILLOCHEAU, F., ROUBY, D., ROBIN, C., HELM, C., ROLLAND, N., LE CARLIER DE VESLUD C. \& BRAUN, J. (2012) Quantification and causes of the terrigeneous sediment budget at the scale of a continental margin: a new method applied to the Namibia-South Africa margin, Basin Research, 24(1), 3-30, doi: 10.1111/j.1365-2117.2011.00511.x

GROOTES, P.M., STUIVER, M., WHITE, J.W.C., JOHNSEN, S. \& JOUZEL, J. (1993) Comparison of oxygen isotope records from the GISP2 and GRIP Greenland ice cores, Nature, 366, 552-554, doi: 10.1038/366552a0 
HEMMING, S.R. (2004) Heinrich events: Massive late Pleistocene detritus layers of the North Atlantic and their global climate imprint, Reviews of Geophysics, 42(1): RG1005 1-43.

HINDERER, M. (2001) Late Quaternary denudation of the Alps, valley and lake fillings and modern river loads, Geodinamica Acta, 14(4), 231-263, doi: 10.1016/S0985-3111(01)010701.

HOVIUS, N., STARK, C.P. \& ALLEN, P.A. (1997) Sediment flux from a mountain belt derived by landslide mapping, Geology, 25(3), 231 - 234, doi : 10.1130/00917613(1997)025<0231:SFFAMB>2.3.CO;2

HOVIUS, N. (1998) Controls on sediment supply by large rivers. In: Relative Role of Eustasy, Climate, and Tectonism in Continental Rocks (Ed. By K.W., Shanley, \& P.J., McCabe), SEPM Special Publication, 59, 3-16, Tulsa, Oklahoma.

JORRY, S.J., DROXLER, A.W., MALLARINO, G., DICKENS, G.R., BENTLEY, S.J., BEAUFORT, L., PETERSON, L.C. \& OPDYKE, B.N. (2008) Bundled turbidite deposition in the central Pandora Trough (Gulf of Papua) since Last Glacial Maximum: linking sediment nature and accumulation to sea level fluctuations at millennial timescale, Journal of Geophysical Research-Earth Surface, 113 (F1), doi: 10.1029/2006jf000649.

JORRY, S.J., JEGOU, I., EMMANUEL, L., SILVA JACINTO, R. \& SAVOYE, B. (2011) Turbiditic levee deposition in response to climate changes: The Var Sedimentary Ridge (Ligurian Sea), Marine Geology, 279, 148-161.

KALLEL, N., DUPLESSY, J.C., LABEYRIE, L., FONTUGNE, M., PATERNE, M. \& MONTACER, M. (2000) Mediterranean pluvial periods and sapropel formation over the last 200000 years, Palaeogeography, Palaeoclimatology, Palaeoecology, 157, 45-58.

KETTNER, A.J., \& SYVITSKI, J.P.M. (2008) Predicting discharge and sediment flux of the Po River, Italy since the Last Glacial Maximum, Special Publication of the International Association of Sedimentologists, 40, 171-189.

KETTNER, A.J., \& SYVITSKI, J.P.M. (2009) Fluvial responses to environmental perturbations in the Northern Mediterranean since the Last Glacial Maximum, Quaternary Science Reviews, 28(23-24), 2386-2397, doi: 10.1016/j.quascirev.2009.05.003.

KUHLEMANN, J., FRISCH, W., SZÉKELY, B., DUNKL, I. \& KÁZMÉR, M. (2002) Postcollisional sediment budget history of the Alps: Tectonic versus climatic control, International Journal of Earth Sciences, 91(5), 818-837.

KUHLEMANN, J., FRISCH, W., SZÉKELY, B., DUNKL, I., DANIŠIK, M. \& KRUMREI, I. (2005): Würmian maximum glaciation in Corsica: glacier extent, amplifying paleorelief, and mesoscale climate, Austrian Journal of Earth Sciences, 97: 68-81.

KUHLEMANN, J., KRUMREI, I., DANISIK, M. \& KLAAS VAN DER, B. (2009) Weathering of granite and granitic regolith in Corsica: short-term 10Be versus long-term thermochronological constraints. In: Thermochronological Methods: From Palaeotemperature Constraints to Landscape Evolution Models, (Ed. by F., Lisker, B., Ventura \& U.A., Glasmacher), Geological Society, London, Special Publications, 324, 217-235, doi: 10.1144/SP324.16.

KUHLEMANN, J., ROHLING, E.J., KRUMREI, I., KUBIK, P., IVY-OCHS, S. \& KUCERA, M. (2008) Circulation During the Last Glacial Maximum Regional Synthesis of Mediterranean Atmospheric, Science, 321, 1338-1340, doi: 10.1126/science.1157638 
LAHONDERE, J.-C., CONCHON, O. \& LAHONDERE, D. (1994) Vescovato, in Carte Géologique de France, Map 1107, scale 1/50000, BRGM, Orléans, France.

LISIECKI, L.E., \& R AYMO, M.E. (2005) A Pliocene-Pleistocene stack of 57 globally distributed benthic $\delta 180$ records, Paleoceanography, 20, PA1003.

LISKER, F., VENTURA, B. \& GLASMACHER, U.A. (2009) Apatite thermochronology in modern geology. In: Thermochronological Methods : From Paleotemperature Constrains to Landscape Evolution Models, (Ed. by F., Lisker, B., Ventura, \& U.A. Glasmacher), Geological Society, London, Special Publication, 324, 1-23, doi: 10.1144/SP324.1

LUCAZEAU, F., \& MAILHE, D. (1986) Heat flow, heat production and fission track data from the Hercynian basement around the Provencal Basin (Western Mediterranean), Tectonophysics, 128(3-4), 335-356, doi: 10.1016/0040-1951(86)90300-8.

MARTINSON, D.G., PISIAS, N.G., HAYS, J.D., IMBRIE, J., M OORE JR., T.C. \& SHACKLETON, N.J. (1987) Age dating and the orbital theory of the ice ages: Development of a high-resolution 0 to 300,000-year chronostratigraphy, Quaternary Research, 27(1), 129, doi:10.1016/0033-5894(87)90046-9.

MARTRAT, B., GRIMALT, J.O., LOPEZ-MARTINEZ, C., CACHO, I., SIERRO, F.J., FLORES, J.A., ZAHN, R., CANALS, M., CURTIS, J.H. \& HODELL, D.A. (2004) Abrupt temperature changes in the Western Mediterranean over the past 250,000 years, Science, 306(5702), 1762-1765, doi:10.1126/science.1101706.

MAUFFRET, A., CONTRUCCI, I. \& BRUNET, C. (1999) Structural evolution of the Northern Tyrrhenian Sea from new seismic data, Marine and Petroleum Geology, 16(5), 381-407, doi: 10.1016/S0264-8172(99)00004-5.

MEDIMAP GROUP, LOUBRIEU, B., MASCLE, J. ET AL. (2005) Morpho-bathymetry of the Mediterranean Sea, CIESM / Ifremer special publication, Atlases and Maps, two maps at 1/2 000 000 ,

link:

http://wwz.ifremer.fr/drogm/cartographie/mediterranee/synthese_carto_mediterranee.

MÉTIVIER, F., GAUDEMER, Y., TAPPONNIER P., \& KLEIN, M. (1999), Mass accumulation rates in Asia during the Cenozoic, Geophysical Journal International, 137(2), 280-318, doi: 10.1046/j.1365-246X.1999.00802.x.

MILLIMAN, J.D., \& SYVITSKI, J.P.M. (1992) Geomorphic/Tectonic Control of Sediment Discharge to the Ocean: The Importance of Small Mountainous Rivers, The Journal of Geology, 100, 525-544, doi: 10.1086/629606

MITCHUM, R.M., VAIL, P.R. \& SANGREE, J.B. (1977) Stratigraphic interpretation of seismic reflection patterns in depositional sequences. part 6. In: Seismic Stratigraphy-Application to Hydrocarbon Exploration, 8th edn, (Ed by C.E. Payton), pp. 117-133, AAPG, Tulsa, Oklahoma.

NESBITT, H.W. \& YOUNG, G.M. (1984) Prediction of some weathering trends of plutonic and volcanic rocks based on thermodynamic and kinetic considerations, Geochim. Cosmochim. Acta, 48(7), 1523-1534, doi: 10.1016/0016-7037(84)0408-3

NGRIP-members (2004) High resolution climate record of the northern hemisphere reaching into the last interglacial period, Nature, 431, 147-151.

NORTON, K.P., ABBÜHL, L.M. \& SCHLUNEGGER, F. (2010) Glacial conditioning as an erosional driving force in the Central Alps, Geology, 38, 655-658, doi: 10.1130/G31102.1. 
PASCUCCI, V., MERLINI, S. \& MARTINI, I.P. (1999) Seismic stratigraphy of the MiocenePleistocene sedimentary basins of the Northern Tyrrhenian Sea and western Tuscany (Italy), Basin Research, 11(4), 337-356, doi: 10.1046/j.1365-2117.1999.00104.x

PATERNE, M., KALLEL, N., LABEYRIE, L., VAUTRAVERS, M., DUPLESSY, J.C., ROSSIGNOL-STRICK, M., CORTIJO, E., ARNOLD, M. \& FONTUGNE, M. (1999) Hydrological relationship between the North Atlantic Ocean and the Mediterranean Sea during the past 15-75 kyr, Paleoceanography, 14, 626-638.

POSAMENTIER, H.W., \& KOLLA, V. (2003) Seismic Geomorphology and Stratigraphy of Depositional Elements in Deep-Water Settings, Journal of Sedimentary Research, 73(3), 367-388, doi:10.1306/111302730367.

REIMER, P.J., BAILLIE, M.G.L., BARD, E., BAYLISS, A., BECK, J. W., BLACKWELL, P.G., BRONK RAMSEY, C., BUCK, C. E., BURR, G., EDWARDS, R. L., FRIEDRICH, M., GROOTES, P. M., GUILDERSON, T. P., HAJDAS, I., HEATON, T.J., HOGG, A.G., HUGHEN, K.A., KAISER, K.F., KROMER, B., MCCORMAC, F.G., MANNING, S.W., REIMER, R.W., RICHARDS, D.A., SOUTHON, J., TURNEY, C.S.M., VAN DER PLICHT, J. \& WEYHENMEYER, C. (2009) IntCal09 and Marine09 radiocarbon age calibration curves, 050,000 years cal BP, Radiocarbon, 51(4), 1111-1150.

RICHTER, T.O., VAN DER GAAST, S., KOSTER, B., VAARS, A., GIELES, R., DE STIGTER, H.C., DE HAAS, H. \& VAN WEERING, T.C.E. (2006) The Avaatech XRF Core Scanner: technical description and applications to NE Atlantic sediments, In: New Techniques in Sediment Core Analysis, (Ed. by R.G., Rothwell), Geological Society, London, Special Publications, 267, 39-50, doi: 10.1144/GSL.SP.2006.267.01.03.

RITTENOUR, T. M. (2008) Luminescence dating of fluvial deposits: applications to geomorphic, palaeoseismic and archaeological research, Boreas, 37, 613-635, doi: 10.1111/j.1502-3885.2008.00056.x.

ROVERI, M. (2002) Sediment drifts of the Corsica Channel, northern Tyrrhenian Sea, In : Deep-Water Contourite Systems: Modern Drifts and Ancient Series, Seismic and Sedimentary Characteristics, (Ed. by D.A.V. Stow, C.J. Pudsey, J.A. Howe, J.-C. Faugères, \& A.R. Viana), Geological Society, London, Memoirs, 191-208, doi: 10.1144/GSL.MEM.2002.022.01.14.

SANCHEZ GONI, M.F., CACHO, I., TURON, J.L., GUIOT, J., SIERRO, F.J., PEYPOUQUET, J.-P., GRIMALT J.O. \& SHACKLETON, N.J. (2002) Synchroneity between marine and terrestrial responses to millenial scale climatic variability during the last glacial period in the Mediterranean region, Climate Dynamics, 19, 95-105.

SHACKLETON, N.J., HALL, M.A., \& VINCENT, E. (2000) Phase relationships between millennial-scale events 64,000-24,000 years ago, Paleoceanography, 15, 565-569.

SIERRO, F.J., ANDERSEN, N., BASSETTI, M.A., BERNÉ, S., CANALS, M., CURTIS, J.H., DENNIELOU, B., FLORES, J.A., FRIGOLA, J., GONZALEZ-MORA, B., GRIMALT, J.O., HODELL, D.A., JOUET, G., PÉREZ-FOLGADO, M. \& SCHNEIDER, R. (2009) Phase relationship between sea level and abrupt climate changes, Quaternary Science Reviews, 28(25-26), 2867-2881.

SØMME, T.O, HELLAND-HANSEN, W., MARTINSEN, O.J. \& THURMOND, J.B. (2009) Relationships between morphological and sedimentological parameters in source-to-sink systems: a basis for predicting semi-quantitative characteristics in subsurface systems, Basin Research, 21(4), 361-387, doi: 10.1111/j.1365-2117.2009.00397.x 
SØMME, T.O, PIPER, D.J.W., DEPTUCK, M.E. \& HELLAND-HANSEN, W. (2011) Linking onshore-offshore sediment dispersal in the Golo source-to-sink system (Corsica, France) during late Quaternary, Journal of Sedimentary Research, 81(2), 118-137, doi: 10.2110/jsr.2011.11

STANLEY, D.J., REHAULT, J.-P., \& STUCKENRATH, R. (1980) Turbid-layer bypassing model: The Corsican Trough, northwestern Mediterranean, Marine Geology, 37(1-2), 19-40, doi: 10.1016/0025-3227(80)90010-9.

STANLEY, D.J. (1989) Sediment Transport on the Coast and Shelf between the Nile Delta and Israeli Margin as Determined by Heavy Minerals, Journal of Coastal Research, 5(4), 813-828

STUIVER, M., \& R EIMER, P.J. (1993) Extended 14C data base and revised CALIB radiocarbon calibration program, Radiocarbon, 35, 215-230.

SVENSSON, A., ANDERSEN, K. K., BIGLER, M., CLAUSEN, H.B., DAHL-JENSEN, D., DAVIES, S. M., JOHNSEN, S. J., MUSCHELER, R., PARRENIN, F., RASMUSSEN, S.O., R"OTHLISBERGER, R., SEIERSTAD, I., STEFFENSEN, J.P. \& VINTHER, B. M. (2008) A 60000 year Greenland stratigraphic ice core chronology, Climate of the Past, 4, 47-57.

SYVITSKI, J.P., \& MOREHEAD, M.D. (1999) Estimating river-sediment discharge to the ocean: application to the Eel Margin, northern California, Marine Geology, 154, 13-28(1-4), doi: 10.1016/S0025-3227(98)00100-5.

SYVITSKI, J.P.M., \& MILLIMAN, J.D. (2007) Geology, Geography, and Humans Battle for Dominance over the Delivery of Fluvial Sediment to the Coastal Ocean, The Journal of Geology, 115(1), 1-19, doi: 10.1086/509246.

TOUCANNE, S., ZARAGOSI, S., BOURILLET, J.F., NAUGHTON, F., CREMER, M., EYNAUD, F., \& DENNIELOU, B. (2008) Activity of the turbidite levees of the CelticArmorican margin (Bay of Biscay) during the last 30,000 years: imprints of the last European deglaciation and Heinrich events, Marine Geology, 247(1-2), 84-103, doi: 10.1016/j.margeo.2007.08.008.

TOUCANNE, S., ZARAGOSI, S., BOURILLET, J-F., MARIEU, V., CREMER, M., KAGEYAMA, M., VAN VLIET-LANOE, B., EYNAUD, F., TURON, J-L., \& GIBBARD, P.L. (2010) The first estimation of Fleuve Manche palaeoriver discharge during the last deglaciation: Evidence for Fennoscandian ice sheet meltwater flow in the English Channel ca 20-18 ka ago, Earth and Planetary Science Letters, 290(3-4), 459-473, doi: 10.1016/j.epsl.2009.12.050.

TOUCANNE, S., JOUET, G., DENNIELOU, B., DUCASSOU, E., BASSETTI, M.A., ANGUE MINTO'O, C., LAHMI, M., TOUYET, N., CHARLIER, K., LERICOLAIS, G., \& MULDER, T. (2012) A 130,000-year record of Levantine Intermediate Water flow variability in the Corsica Trough, western Mediterranean Sea, Quaternary Science Reviews, 33, 55-73, doi: 10.1016/j.quascirev.2011.11.020.

TURCOTTE, D.L., \& SCHUBERT, G. (2002) Geodynamics, 2nd edn, Cambridge University Press, Cambridge, $472 \mathrm{p}$.

TZEDAKIS, P.C., MCMANUS, J.F., HOOGHIEMSTRA, H., OPPO, D.W. \& WIJMSTRA, T.A. (2003) Comparison of changes in vegetation in northeast Greece with records of climate variability on orbital and suborbital frequencies over the last 450000 years, Earth and Planetary Science Letters, 212(1-2), 197-212, doi: 10.1016/S0012-821X(03)00233-4. 
VALLA, P.G., HERMAN, F., VAN DER BEEK, P.A. \& BR AUN J. (2010) Inversion of thermochronological age-elevation profiles to extract independent estimates of denudation and relief history - I: Theory and conceptual model, Earth and Planetary Science Letters, 295(3-4), 511-522, doi: 10.1016/j.epsl.2010.04.033.

VON BLANCKENBURG, F. (2005) The control mechanisms of erosion and weathering at basin scale from cosmogenic nuclides in river sediment, Earth and Planetary Science Letters, 237, 462-479, doi: 10.1016/j.epsl.2005.06.030.

VAN DER BEEK, P.A., VALLA, P.G., HERMAN, F., BRAUN, J., PERSANO, C., DOBSON, K.J. \& LABRIN, E. (2010) Inversion of thermochronological age-elevation profiles to extract independent estimates of denudation and relief history - II: Application to the French Western Alps, Earth and Planetary Science Letters, 296(1-2), 9-22, doi: 10.1016/j.epsl.2010.04.032.

WAELBROECK, C., LABEYRIE, L., MICHEL, E., DUPLESSY, J.C., MCMANUS, J.F., LAMBECK, K., BALBON, E. \& LABRACHERIE, M. (2002) Sea-level and deep water temperature changes derived from benthic foraminifera isotopic records, Quaternary Science Reviews, 21(1-3), 295-305, doi: 10.1016/S0277-3791(01)00101-9.

WALFORD, H.L., WHITE, N.J. \& SYDOW, J.C. (2005) Solid sediment load history of the Zambezi Delta, Earth and Planetary Science Letters, 238(1-2), 49-63, doi: 10.1016/j.epsl.2005.07.014.

WILLENBRING, J. K., \& VON BLANCKENBURG, F. (2010) Long-term stability of global erosion rates and weathering during late-Cenozoic cooling, Nature, 465, 211-214, doi: 10.1038/nature09044.

WILLETT, S.D., SCHLUNEGGER, F. \& PICOTTI, V. (2006) Messinian climate change and erosional destruction of the central European Alps, Geology, 34, 613-616.

ZARKI-JAKNI, B., VAN DER BEEK, P., POUPEAU, G., SOSSON, M., LABRIN, E., ROSSI, P., \& FERRANDINI, J. (2004) Cenozoic denudation of Corsica in response to Ligurian and Tyrrhenian extension: Results from apatite fission track thermochronology, Tectonics, 23, TC1003, doi: 10.1029/2003TC001535.

\section{Figures}



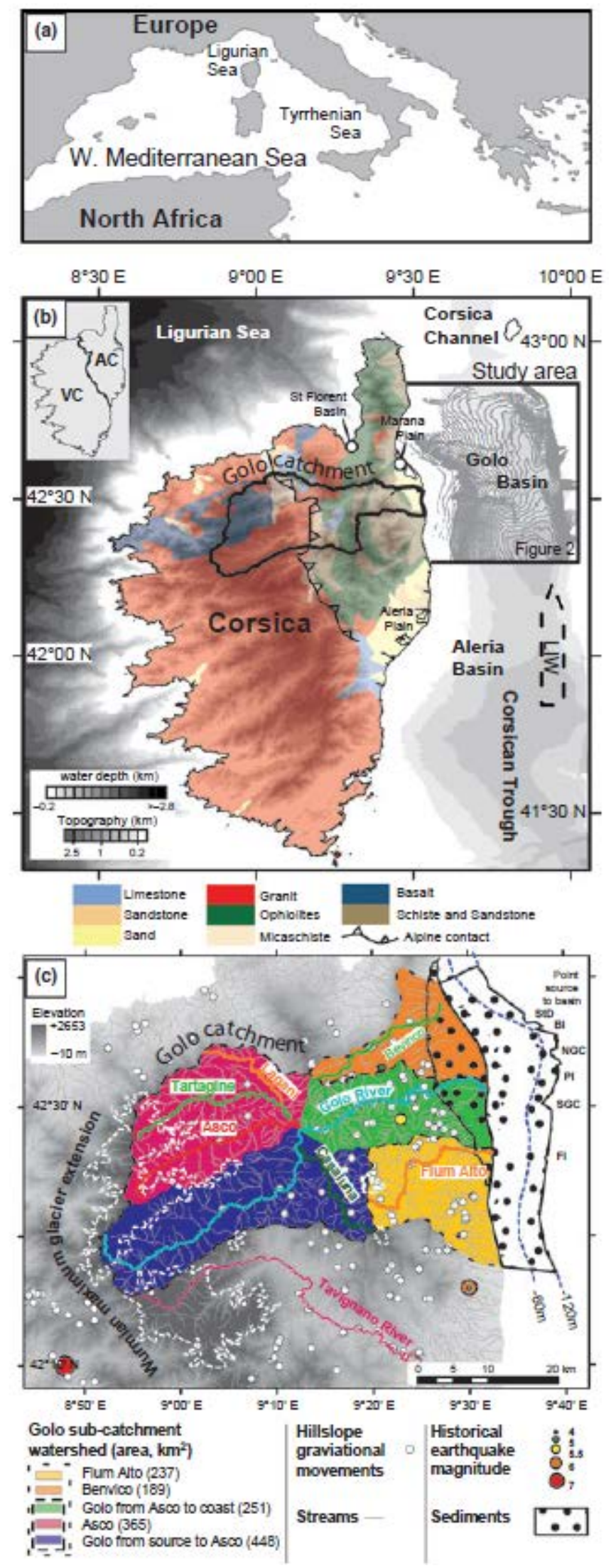

Figure 1: Regional setting of the study, (A) position of Corsica Island in the Western Mediterranean Sea, (B) elevation and bathymetry of Corsica (SRTM data for elevation and MediMap Group (2005) for bathymetry), the bedrock geology of Corsica is draped on the elevation map, division between Alpine and Variscan Corsica is outlined in the inset, the study area from the Golo catchment to the Golo Basin offshore is outline by a bold black line, the Levantine Intermediate Water (LIW) current running northward within the Corsica Trough 
is represented by a dashed arrow, the different point sources to the slope and basin are from north to south: Saint Damiano (StD), Biguglia (Bi), North Golo Canyon (NGC), Pineto (Pi) and South Golo Canyon (SGC), (source: http://sandre.eaufrance.fr) (C) Golo catchment and drainage system overlay on SRTM topography. Present day drainage of the Golo catchment and paleo-drainage (over the last $130 \mathrm{ka}$ ) are contoured by dashed polygons. Earth surface processes (hillslope gravitational movements - white circles, mass movements data source: http://infoterre.brgm.fr/) are focused towards the eastern part of the Golo catchment within the Alpine Corsica domain (Figure 1B). Low historical earthquake magnitude (data source: http://www.sisfrance.net/) within the study area leads to interpret the role of deformation to play a minor role in the evolution of the studied area. The maximum extension of glaciers is based after Kuhlemann et al. [2008, 2009]. 

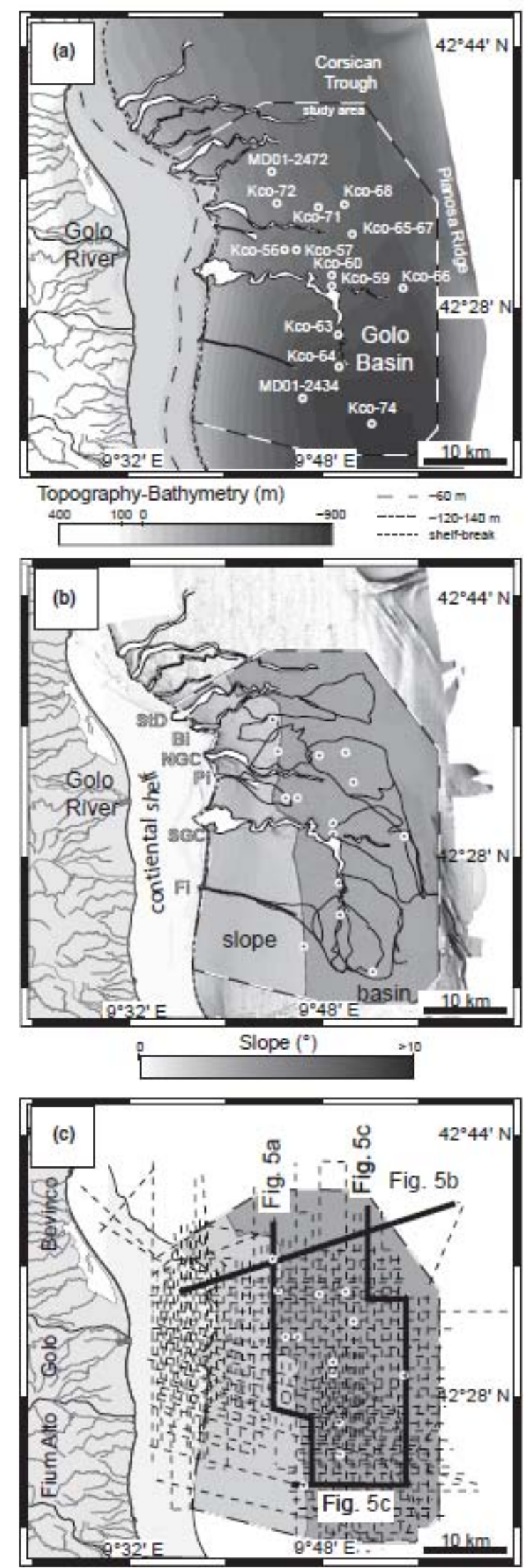

Figure 2: (A) Topography-bathymetry map of the study area, (B) morphological element overlaying slope map (grey shaded), outline of seismically mapped sedimentary lobes below the seafloor (bold black line), slope and basin area are defined by slope change from 1-2.5 to $<1^{\circ}$, and $(\mathrm{C})$ base map of $2 \mathrm{D}$ seismic reflection grid (sub-bottom profiler and sparker) used for this study, bold black are seismic lines location of Figure 5. Circles: core locations (KCO and MD); outlined polygon (dash black-white): extent of region considered in this study. 

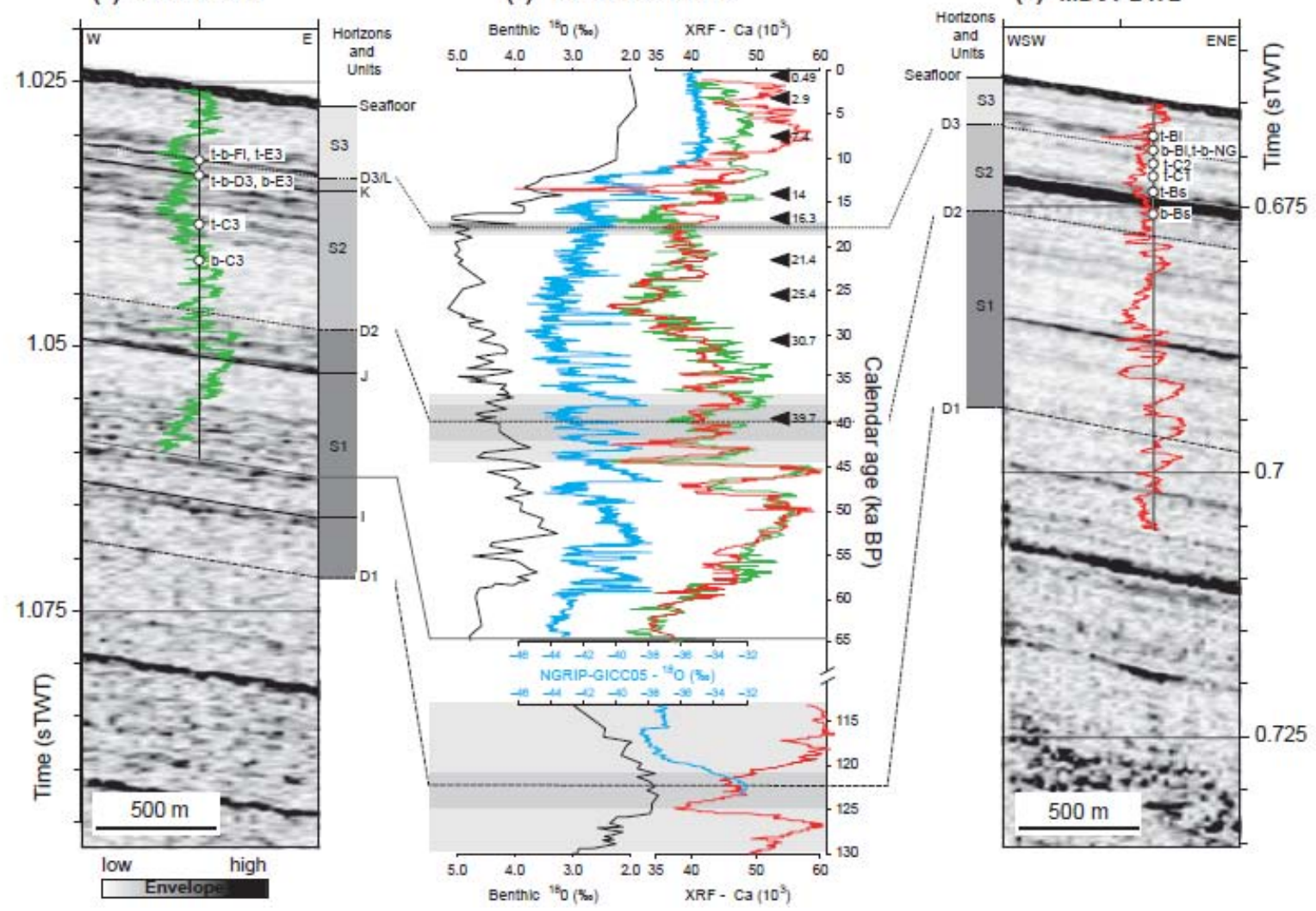

Figure 3: Seismic sub-bottom profiler data and regional calibration at MD cores location. (A) MD01-2472 (red) corresponding to the North Golo area and (B) MD01-2434 (green) to the South Golo area. Seismic horizons and units are displayed on the right of each seismic panel. At core MD01-2434, seismic horizons I, J, and K and L refers to the study of Gervais [2002]. (C) The seismic framework is tied at both sites with cores data and constrained by chronostratigraphic data, thus illustrated by the benthic ${ }^{18} \mathrm{O}$ isotope curve from core MD012434 (black curve), XRF Ca counts (red/green) calibrated by ${ }^{14} \mathrm{C}$ (black triangles) and NGRIP-GICC05 ${ }^{18} \mathrm{O}$ isotope plot (blue curve). Age model constraints and build up are detailed in the text. The age uncertainties of seismic horizons related to the tie between seismic and core data (i.e., seismic resolution and velocity) correspond to the gray shaded bars. At each MD site (within its vicinity) we locate by a circle the top (t) and base (b) of the architectural element present in the basin. 

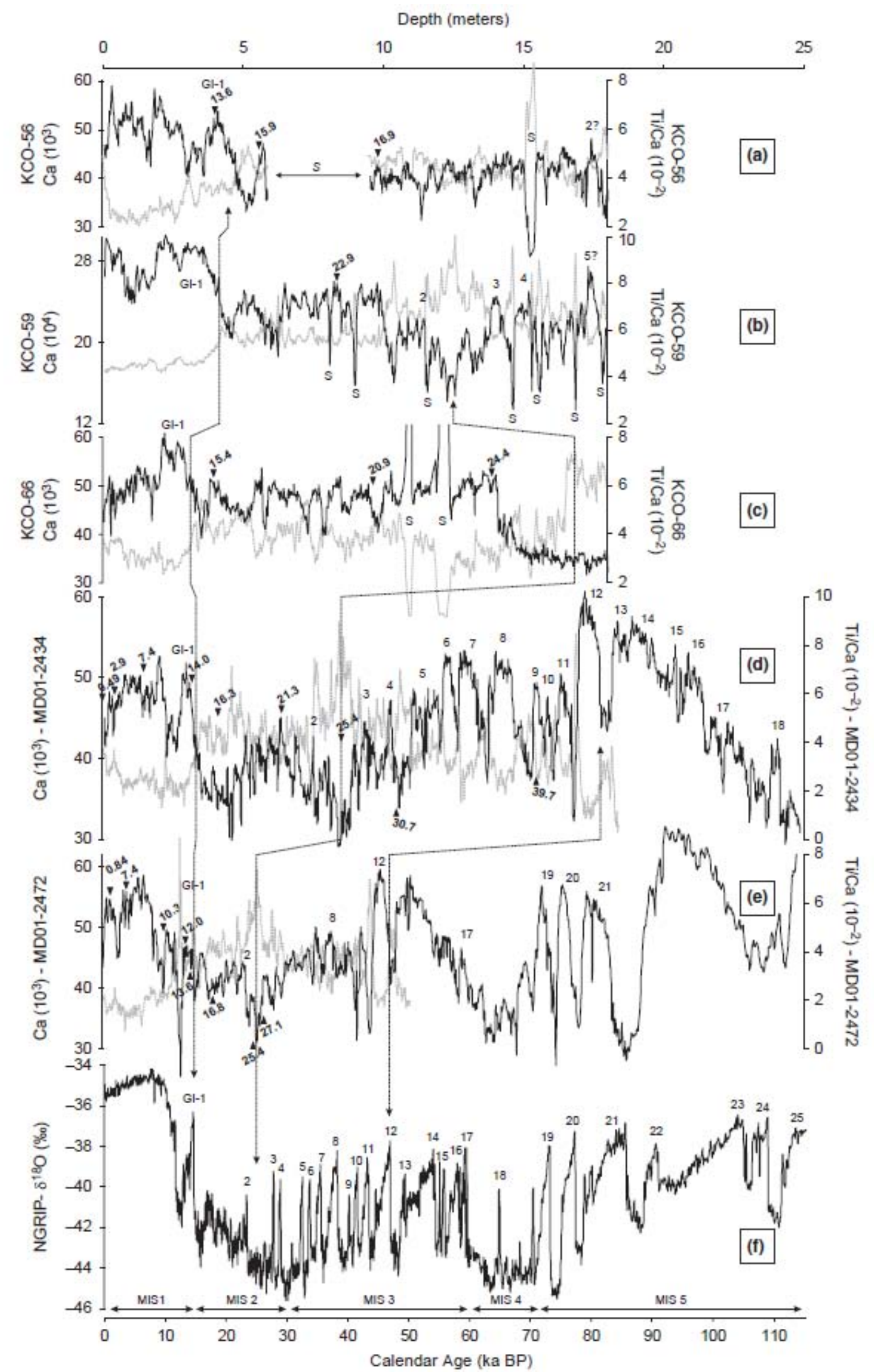
Figure 4: Downcore records of XRF-derived Ca (black lines) and Ti/Ca ratio (dashed grey lines) from cores located $(A)$ in the continental slope (KCO-56), (B) on a sedimentary levee $(\mathrm{KCO}-59)$ and $(\mathrm{C})$ in the deep-basin (KCO-66) of the Corsica Trough (the length of these cores has been multiplied by two for a better readability of the data; S: sandy deposits). Their chronostratigraphic framework lies on the correlation with the XRF records of the neighboring long-piston cores MD01-2434 (in depth) (D) and MD01-2472 (in age) (E) which show a striking resemblance with the NGRIP record (F) (GICC05 chronology up to $60 \mathrm{ka}$, NGRIP thereafter) [NGRIP-members, 2004; Svensson et al., 2008]. The Greenland Interstadials (GI) are indicated. Black triangles indicate the position of the AMS 14C dates (calibrated age, ka cal. BP in bold, Appendix A - Table 2 - see Toucanne et al., 2012 for details).
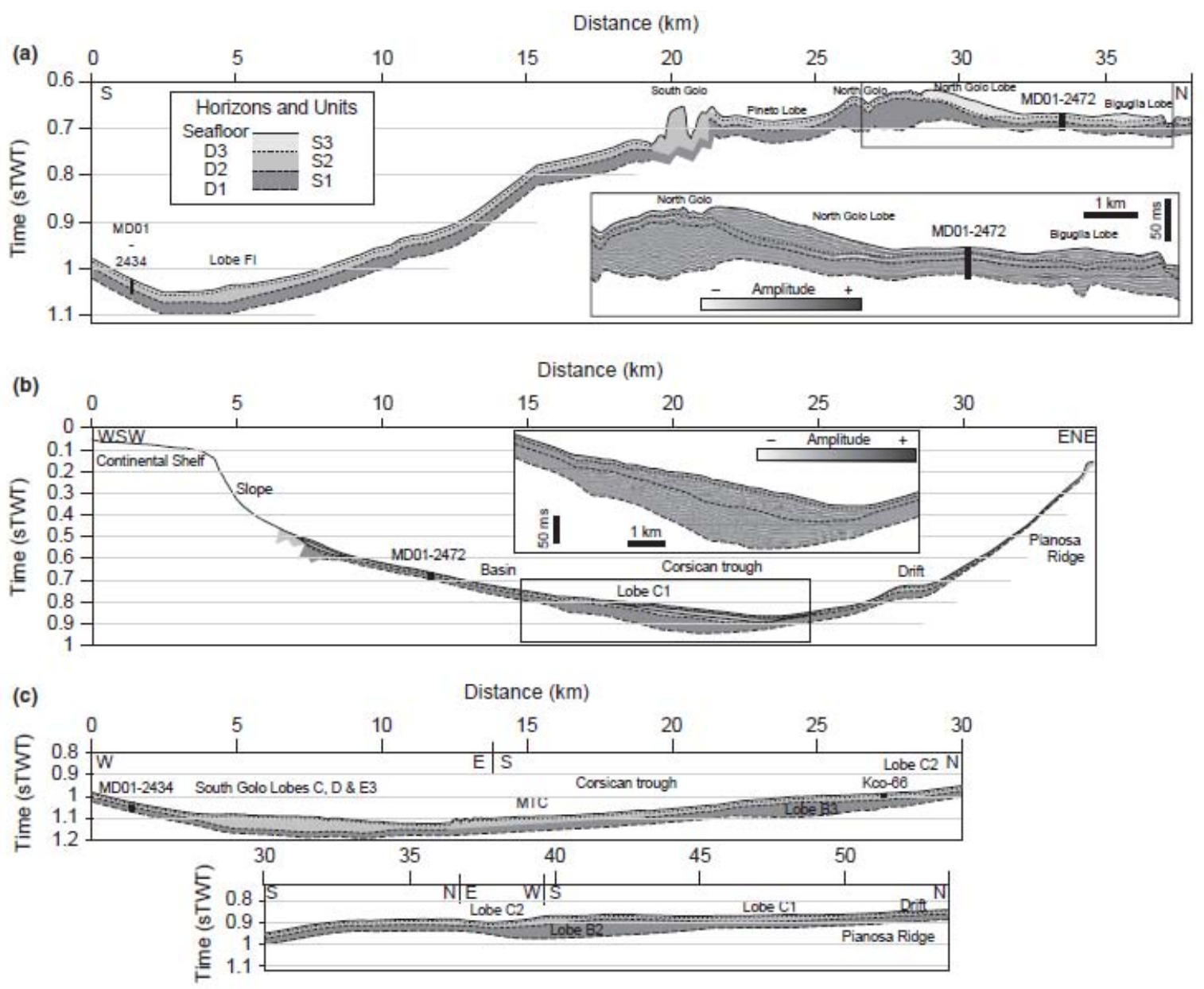

Figure 5: Golo Basin seismic stratigraphic framework, location of profiles in Figure 2C. The $\mathrm{N}-\mathrm{S}$ proximal profile $(\mathrm{A})$, illustrates the two mains conduits of sediments towards the Golo Basin with presence of the North and South Golo canyons-channel-levee systems. The WSW-ENE profile (B) highlights the confined geometry of the Golo Basin and single source of sediments coming from the east Corsica continental shelf. The N-S distal profile (C) runs through the Corsican trough and the distal portion of the sedimentary profile and with terminal depositional features such as sedimentary deep-water lobe. Main calibrated core studies running on these profiles are located. Note that vertical and horizontal scales vary from one profile to another. The displays are zero phase, SEG normal polarity, i.e., black peak indicating an increase in acoustic impedance. 


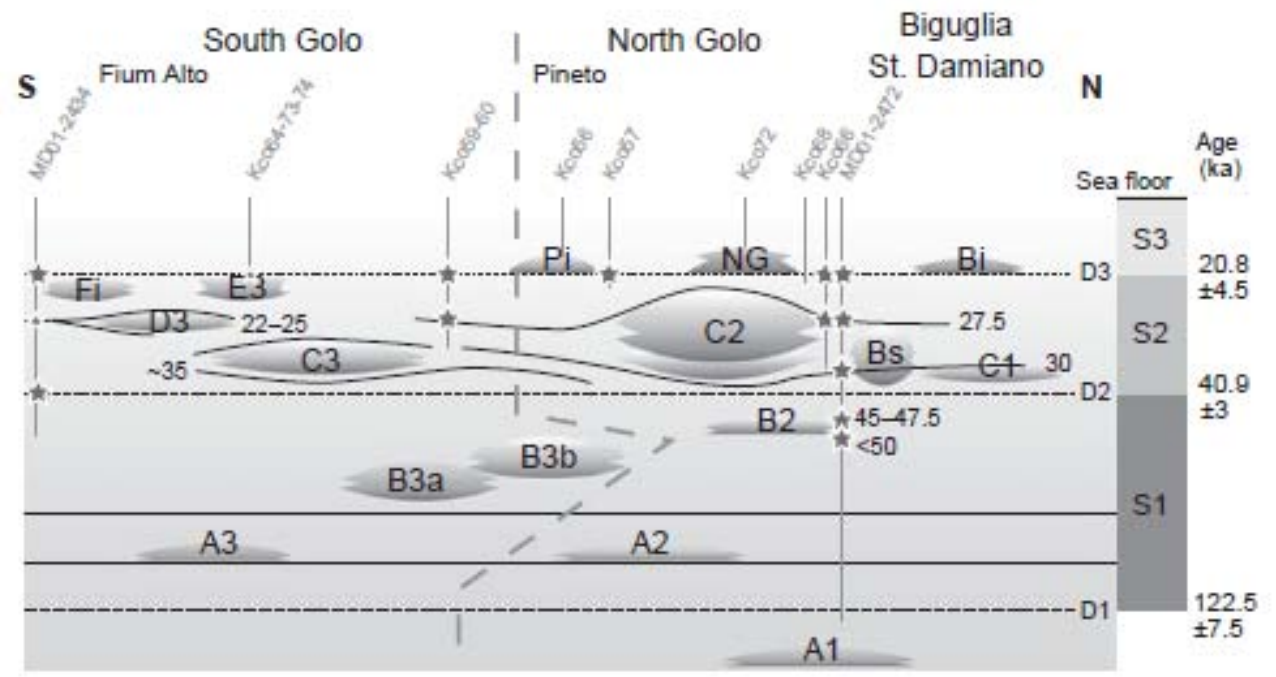

Figure 6: Chronostratigraphic framework of the Golo Basin/Fan. Details of the units and lobe, age, and duration are listed in Appendix A - Table 3. Figure inspired by Deptuck et al. [2008]. Stars mark the calibrated radiocarbon ages.

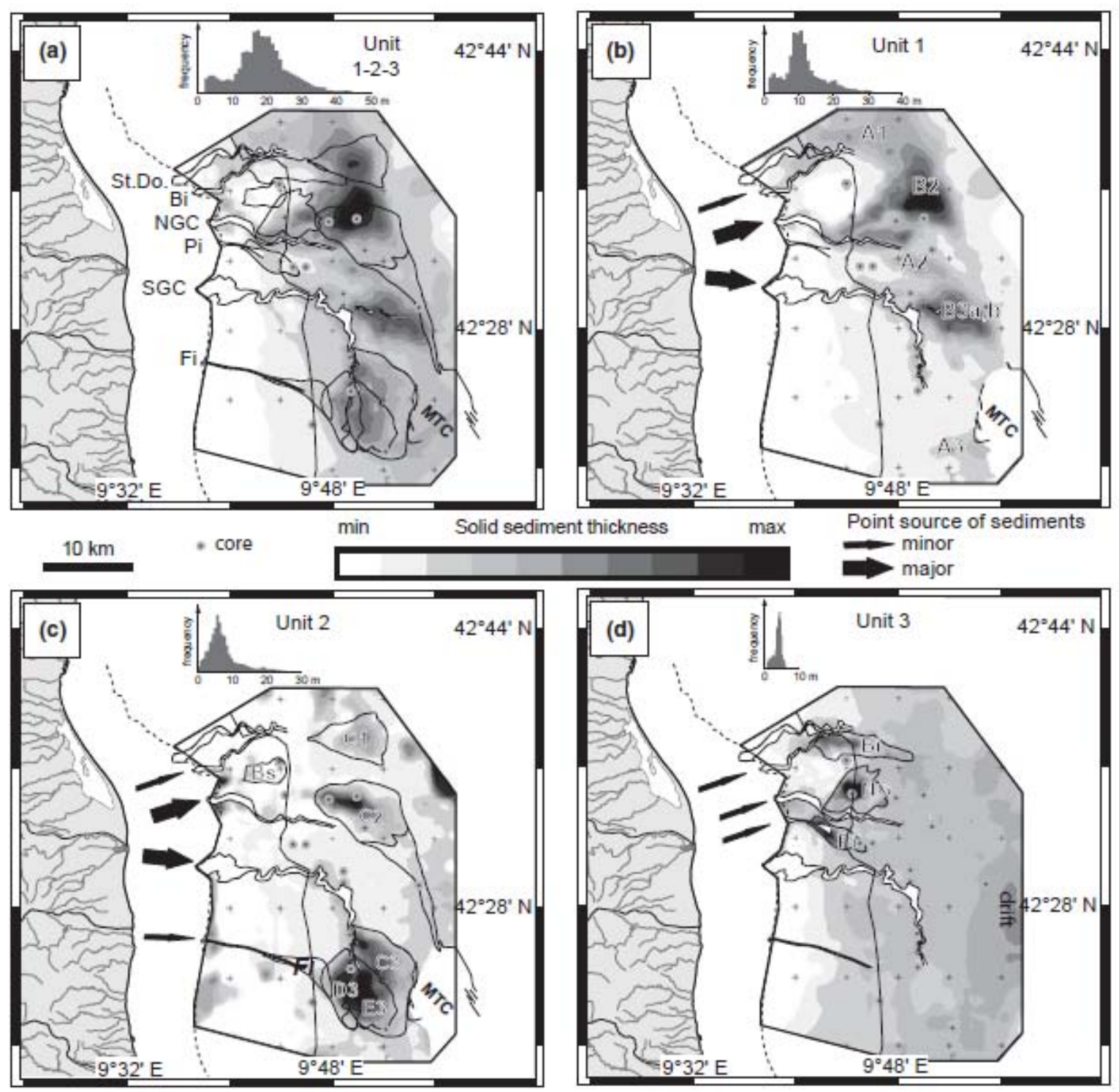


Figure 7: Solid sediment thickness maps of the units used in this study. Each map is associated with its frequency thickness histogram. Black arrows on the shelf are associated to the origin of sediment sourced to the basin by each canyon. Mass transport complex (MTC) are excluded for the volumetrics of units 1 and 2. Circles: core locations (KCO and $\mathrm{MD}$ ); outlined polygon (dash black-white): extent of region considered in this study.

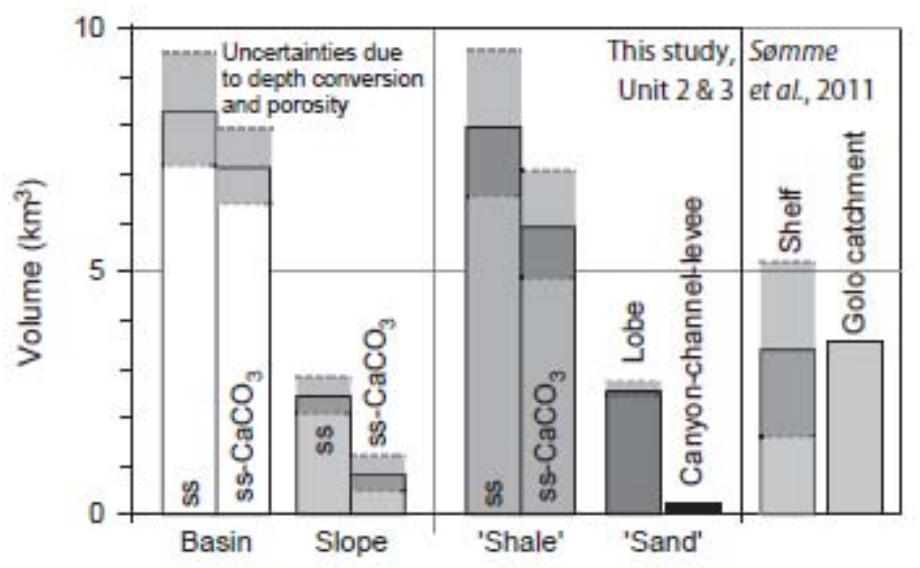

Figure 8: Volumetric comparison of solid sediment (ss) between sedimentary domains, basin and slope, of the summed sedimentary units 2 and 3 . Bulk solid sediment values are compared to values corrected from carbonate removal $\left(\mathrm{ss}-\mathrm{CaCO}_{3}\right)$, showing a decrease of the bulk value by a maximum of $25 \%$. The contrast of volume hosted by the slope and basin is important, this giving power to the estimate of basin volume estimation trough time versus other part of the source to sink continuum. As the comparison of fine grained ('shale') to coarse grained ('sand') sediment composition, highlighting the fact that architectural elements such as channel levee and lobes represent a limited fraction of the sediment deposited in the study area. The volumetric estimates of shelf and Golo catchment are from Sømme et al. [2011]. 

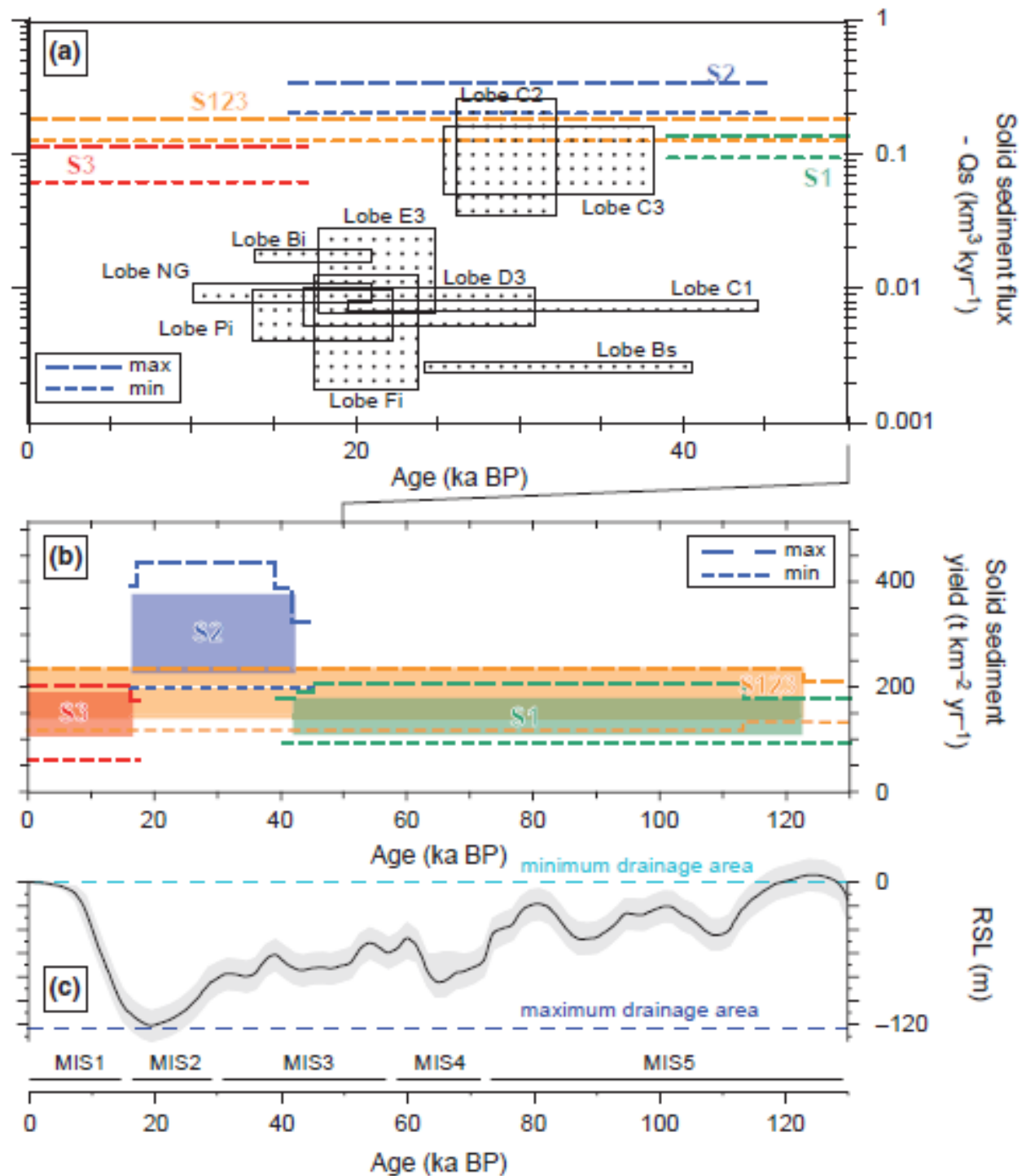

Figure 9: Summary of solid deposition rates after 130 ka. (A) solid sediment flux of depositional elements in the Golo Basin are compared for the last 50 ka to minimum average values of units S1 to S3, highlighting the 1 to $>10$ fold differences of flux recorded between the architectural elements and stratigraphic units. Note the boxes for each deepwater elements (lobe) take into account the uncertainties related to age calibration and volumetric estimates. (B) last climatic cycle $\sim 130$ ka solid sediment yield with all uncertainties calibrated during the study (age, time-depth conversion, volume of sediments), boxes represent the average age model and minimum/maximum yields. (C) relative sea-level curve covering the last climatic cycle and marine isotopic stages (MIS) based on Waelbroeck et al., [2002], the calibrated architectural elements falls in the late MIS4 to MIS2 relative sea-level fall. 

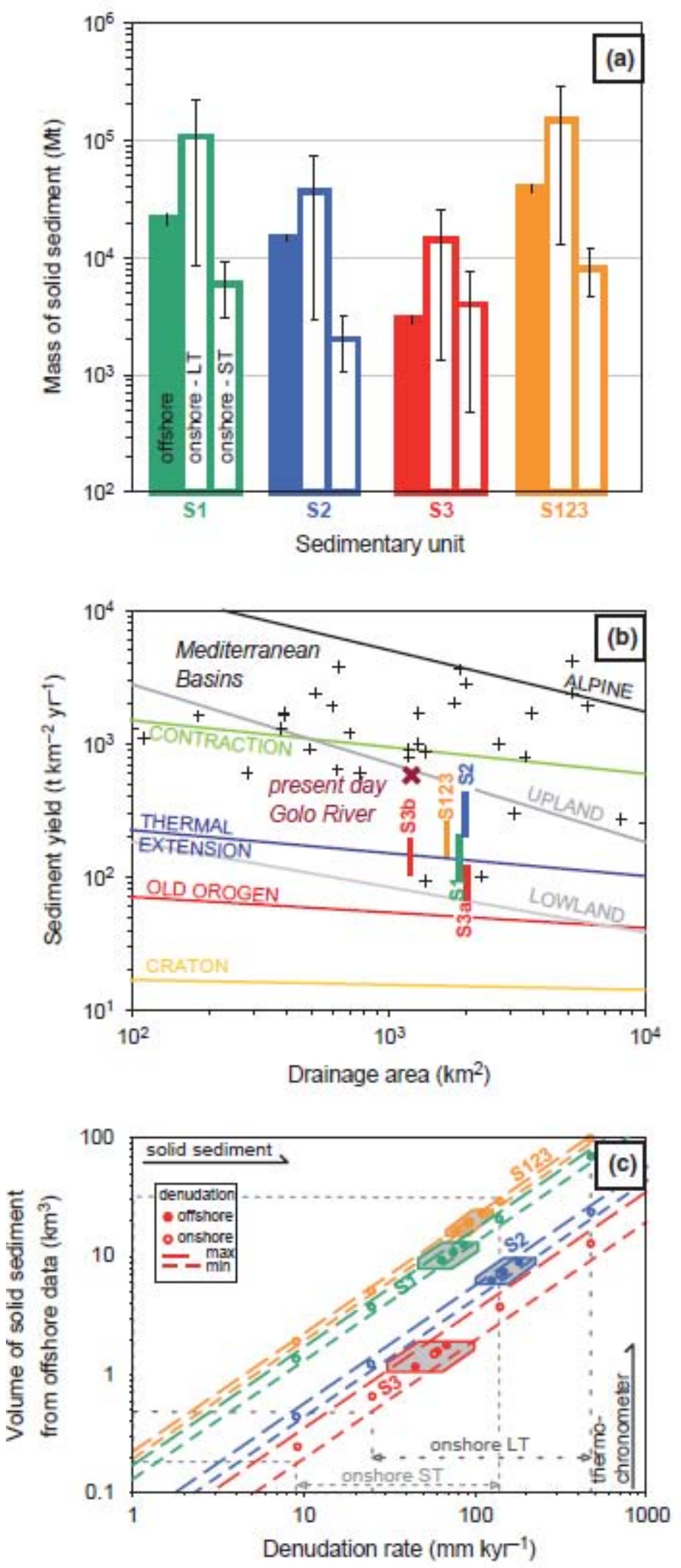

Figure 10: (A) Mass balance of the Golo source-to-sinksystem for the three units studied, volume of solid sediments offshore have been converted using a density of grain of 2700 $\mathrm{kg} / \mathrm{m}^{3}$, the mass of solid sediment for onshore were computed using denudation rates from thermochronometer data (long term (LT), and short term (ST); see Appendix A - Table 4), (B) sediment yield - drainage area plot of the three units recorded in the last climatic cycle in the Golo Basin, black crosses for Mediterranean basins extracted from Table 1 in Milliman and Syvitsky [1992], relationship for alpine, upland and lowland are from Milliman and Syvitsky 
[1992], relationship for tectonic settings: contraction, thermal extension, old orogen and craton are from Hovius [1998], see manuscript for discussion, note that S3a and S3b are computed for different drainage catchment area (S3a: $2006 \mathrm{~km}^{2}$ and S3b: $1214 \mathrm{~km}^{2}$ ) (C) average denudation rate - volume of solid sediment plot estimated from the three units in the marine record compared to thermochronometer measurements within the Golo catchment [e.g.: Fellin et al., 2005b; Kuhlemann et al., 2009]. The uncertainties for each unit (i.e., minimum-maximum values) are plotted and outlined by gray boxes.

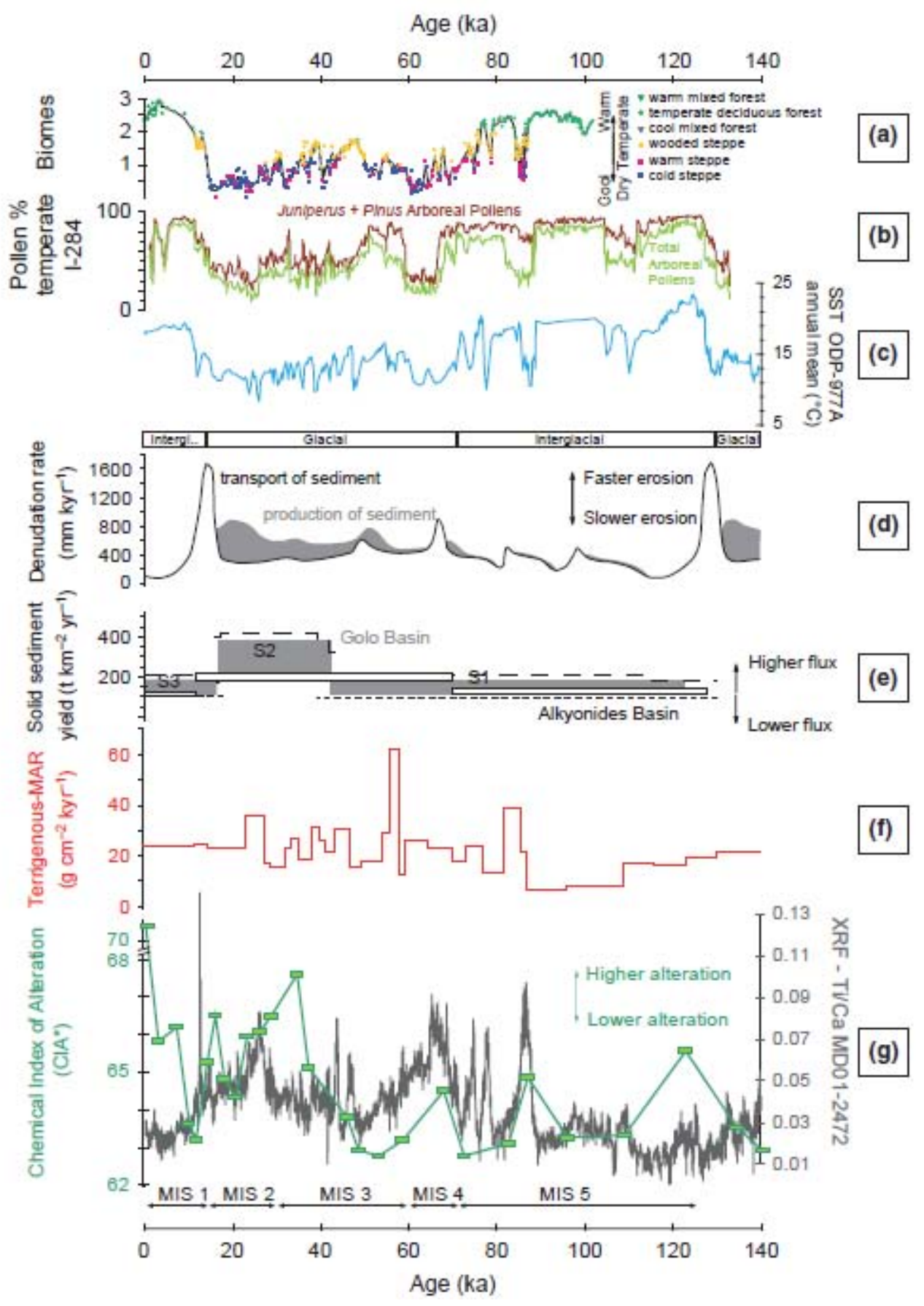

Figure 11: (A) Biomes evolution at Monticchio - Italy during the last $100 \mathrm{kyr}$ [Allen et al., 1999], (B) Arboreal pollens evolution over the last $130 \mathrm{ky}$ in core sediments from lake loannina - Greece [Tzedakis et al., 2002], (C) sea surface temperature record from ODP Site 977A - Alboran Sea [Martrat et al., 2004] and inter-glacial/glacial periods, (D) Alps denudation rates from the last $140 \mathrm{kyr}$ with estimate of production (grey shaded) and transport of sediment (black curve) [Hinderer, 2001], (E) solid sediment yield from the Golo Corsica (grey filled boxes) and Alkyonides Basin - Central Greece (white boxes) [Collier et al., 2000], (F) terrigeneous mass accumulation rates (MAR, in red), and (G) chemical index 
of alteration ( $\mathrm{CIA}^{*}$, in green) as proxies for source chemical weathering over the last $130 \mathrm{kyr}$ from core MD01-2472, with XRF Ti/Ca ratio (light grey) as solid sediment sourcing. Marine Isotopic Stages: MIS.

\section{Appendix A. Supplementary data}

Table 1, Calvès et al., 2012

\begin{tabular}{|c|c|c|c|c|c|c|}
\hline $\begin{array}{l}\text { Core } \\
\text { name }\end{array}$ & Cruise & Type & $\begin{array}{l}\text { Location } \\
\text { latitude }\end{array}$ & longitude & $\begin{array}{l}\text { Water depth } \\
\text { (m) }\end{array}$ & $\begin{array}{l}\text { Recovery } \\
\text { (m) }\end{array}$ \\
\hline $\begin{array}{l}\text { MD01- } \\
2434 \\
\text { MD01- }\end{array}$ & $\begin{array}{l}\text { MD123- } \\
\text { GEOSCIENCES1 } \\
\text { MD124- }\end{array}$ & Calypso & 42,3751 & 9,784 & 780 & 24,93 \\
\hline 2472 & GEOSCIENCES2 & Calypso & 42,607 & 9,73283 & 501 & 29,08 \\
\hline Kco-64 & Corfan2 & kullenberg & 42,4085 & 9,82483 & 726 & 8,26 \\
\hline Kco-73 & Corfan2 & kullenberg & 42,3833 & 9,83316 & 817 & 2,82 \\
\hline Kco-74 & Corfan2 & kullenberg & 42,3503 & 9,8706 & 868 & 4,9 \\
\hline Kco-59 & Corfan2 & kullenberg & 42,4903 & 9,81616 & 652 & 8,71 \\
\hline Kco-60 & Corfan2 & kullenberg & 42,501 & 9,81533 & 571 & 8,46 \\
\hline Kco-56 & Corfan2 & kullenberg & 42,52683 & 9,74983 & 543 & 9,11 \\
\hline Kco-57 & Corfan2 & kullenberg & 42,5266 & 9,7645 & 571 & 10,09 \\
\hline Kco-72 & Corfan2 & kullenberg & 42,574 & 9,7395 & 482 & 5,67 \\
\hline Kco-68 & Corfan2 & kullenberg & 42,5735 & 9,83366 & 621 & 7,25 \\
\hline Kco-66 & Corfan2 & kullenberg & 42,4883 & 9,91416 & 745 & 8,92 \\
\hline
\end{tabular}

Table 1: Core information and location processed for this study. 


\begin{tabular}{|c|c|c|c|c|c|c|}
\hline $\begin{array}{l}\text { Core } \\
\text { number }\end{array}$ & & Lab code & & Cal BP age & Cal BP age & Data origin \\
\hline & $(\mathrm{cm})$ & & age (yr BP) & ranges $(2 \sigma)$ & $\begin{array}{l}\text { median } \\
\text { probability }\end{array}$ & \\
\hline MD01-2434 & 0 & bulk planktic Poz-32034 & $470 \pm 30$ & $443-536$ & 493 & $\begin{array}{l}\text { Toucanne et al., } \\
2012\end{array}$ \\
\hline MD01-2434 & 48 & bulk planktic Poz-32035 & $2,760 \pm 35$ & $2,836-3,072$ & 2,949 & $\begin{array}{l}\text { Toucanne et al., } \\
2012\end{array}$ \\
\hline MD01-2434 & 151 & bulk planktic LLNL-87510 & $6,545 \pm 40$ & $7,382-7,546$ & 7,453 & Gervais, 2002 \\
\hline MD01-2434 & 329 & bulk planktic Poz-32037 & $12,180 \pm 80$ & $13,787-14,251$ & 114,030 & $\begin{array}{l}\text { Toucanne et al., } \\
2012\end{array}$ \\
\hline MD01-2434 & $429^{*}$ & bulk planktic Poz-32038 & $13,300 \pm 90^{*}$ & $15,565-16,797$ & $716,321^{*}$ & $\begin{array}{l}\text { Toucanne et al., } \\
2012\end{array}$ \\
\hline MD01-2434 & 639 & bulk planktic Poz-32039 & $17,900 \pm 130$ & $20,851-21,785$ & 521,363 & $\begin{array}{l}\text { Toucanne et al., } \\
2012\end{array}$ \\
\hline MD01-2434 & 849 & bulk planktic Poz-32041 & $21,290 \pm 180$ & $24,956-25,990$ & 025,443 & $\begin{array}{l}\text { Toucanne et al., } \\
2012\end{array}$ \\
\hline MD01-2434 & 1058 & bulk planktic Poz-32042 & $25,900 \pm 400$ & $30,135-31,196$ & 630,644 & $\begin{array}{l}\text { Toucanne et al., } \\
2012\end{array}$ \\
\hline MD01-2434 & 1552 & bulk planktic LLNL-88144 & $34,640 \pm 220$ & $38,898-40,419$ & 939,657 & Gervais, 2002 \\
\hline MD01-2434 & 2489 & bulk planktic LLNL-87511 & $41,600 \pm 500$ & $44,362-45,855$ & 545,095 & Gervais, 2002 \\
\hline MD01-2472 & 5 & bulk planktic SacA19752 & $910 \pm 30$ & $760-916$ & 842 & $\begin{array}{l}\text { Toucanne et al., } \\
2012\end{array}$ \\
\hline MD01-2472 & 70 & bulk planktic SacA19754 & $3645 \pm 30$ & $3,875-4,009$ & 3,960 & $\begin{array}{l}\text { Toucanne et al., } \\
2012\end{array}$ \\
\hline MD01-2472 & 180 & bulk planktic SacA19756 & $9100 \pm 35$ & 10,196 & 4 & $\begin{array}{l}\text { Toucanne et al., } \\
2012\end{array}$ \\
\hline MD01-2472 & 220 & bulk planktic SacA19757 & $10,240 \pm 40$ & $11,812-12,121$ & 111,990 & $\begin{array}{l}\text { Toucanne et al., } \\
2012\end{array}$ \\
\hline MD01-2472 & 290 & bulk planktic SacA19753 & $11,790 \pm 50$ & $13,453-13,786$ & 613,641 & $\begin{array}{l}\text { Toucanne et al., } \\
2012\end{array}$ \\
\hline MD01-2472 & $380^{*}$ & bulk planktic SacA19758 & $13,720 \pm 45^{\star}$ & $16,692-17,018$ & $816,850 *$ & $\begin{array}{l}\text { Toucanne et al., } \\
2012\end{array}$ \\
\hline MD01-2472 & 580 & bulk planktic SacA19755 & $21230 \pm 140$ & $24,962-25,867$ & 725,367 & $\begin{array}{l}\text { Toucanne et al., } \\
2012\end{array}$ \\
\hline MD01-2472 & 600 & bulk planktic SacA19760 & $22380 \pm 100$ & $26,558-27,716$ & 627,063 & $\begin{array}{l}\text { Toucanne et al., } \\
2012\end{array}$ \\
\hline KCO-56 & 210 & bulk planktic Poz-33953 & $11,740 \pm 70$ & $13,408-13,769$ & 913,588 & this study \\
\hline KCO-56 & $290^{*}$ & bulk planktic Poz-33954 & $13,120 \pm 70^{*}$ & $15,233-16,491$ & $115,917^{*}$ & this study \\
\hline $\mathrm{KCO}-56$ & $415^{*}$ & bulk planktic Poz-33955 & $13,790 \pm 120^{*}$ & $16,652-17,181$ & $116,901^{*}$ & this study \\
\hline KCO-59 & 399 & bulk planktic LLNL-88544 & $17,770 \pm 60$ & $20,867-21,512$ & 221,265 & Gervais, 2002 \\
\hline KCO-59 & 850 & bulk planktic LLNL-88545 & $19,340 \pm 60$ & $22,626-23,428$ & 823,046 & Gervais, 2002 \\
\hline KCO-64 & $70^{*}$ & bulk planktic LLNL-87507 & $13,745 \pm 35^{\star}$ & $16,716-17,028$ & $816,866^{*}$ & Gervais, 2002 \\
\hline KCO-64 & 456 & bulk planktic SacA21238 & $15,450 \pm 50$ & $18,552-18,829$ & 918,829 & this study \\
\hline $\mathrm{KCO}-64$ & 533 & bulk planktic SacA21237 & $16,040 \pm 50$ & $18,929-19,414$ & 419,414 & this study \\
\hline KCO-66 & $190^{*}$ & bulk planktic Poz-32031 & $12,890 \pm 90^{*}$ & $14,976-16,192$ & $215,425^{*}$ & this study \\
\hline KCO-66 & 474 & bulk planktic LLNL-88546 & $17,620 \pm 160$ & $20,460-21,439$ & 920,976 & Gervais, 2002 \\
\hline $\mathrm{KCO}-66$ & 685 & bulk planktic Poz-32032 & $20,440 \pm 170$ & 23,916-24,904 & 424,391 & this study \\
\hline $\mathrm{KCO}-72$ & 123 & bulk planktic SacA21239 & $11,375 \pm 35$ & $13,137-13,349$ & 913,249 & this study \\
\hline KCO-74 & 395 & bulk planktic LLNL-88143 & $16,980 \pm 110$ & $19,827-20,441$ & 120,165 & Gervais, 2002 \\
\hline
\end{tabular}

Table 2: Radiocarbon ages of MD- and Kco-cores. 
Table 2 : Radiocarbon ages of MD- and Kco-cores. The age dates were corrected for a marine reservoir effect of 400 years, except for the period 15-17 ka (marked by an asterisk) for which a correction of 800 years was applied (cf. Siani et al., 2001). Radiocarbon ages were calibrated to calendar years using CALIB 6.0.1 and the IntCal09 calibration curve (Reimer et al., 2009). Note that the radiocarbon date of ca $42{ }^{14} \mathrm{C} \mathrm{ka}$ at the base of core MD01-2434 (Gervais, 2002; Gervais et al., 2006; Sømme et al., 2011) has been removed in the revised chronological framework used in this study (see Toucanne et al., 2012 for details).

\section{References :}

Gervais, A. (2002), Analyse multi-échelles de la morphologie, de la géométrie et de l'architecture d'un système turbiditique sableux profond (système du Golo, marge est Corse, mer Méditerranée), Unpublished $\mathrm{PhD}$ thesis, University Bordeaux 1, $\mathrm{n}^{\circ} 2621,285 \mathrm{pp} . \quad$ http://www.asf.epoc.ubordeaux1.fr/theses/Manuscrits/GERVAIS 2002.pdf.

Gervais, A., T. Mulder, B. Savoye, and E. Gonthier (2006b), Sediment distribution and evolution of sedimentary processes in a small sandy turbidite system (Golo system, Mediterranean Sea): implications for various geometries based on core framework, Geo-Marine Letters, 26(6), 373-395, doi:10.1007/s00367-006-0045-z.

Reimer, P. J., Baillie, M. G. L., Bard, E., Bayliss, A., Beck, J. W., Blackwell, P. G., Bronk Ramsey, C., Buck, C. E., Burr, C. S., R.L., E., Friedrich, M., Grootes, P. M., Guilderson, T. P., Hajdas, I., Heaton, T. J., Hogg, A. G., Hughen, K. A., Kaiser, K. F., Kromer, B., McCormac, F. G., Manning, S. W., Reimer, R. W., Richards, D. A., Southon, J. R., Talamo, S., RTurney, C. S. M., Van der Plitch, J., Weyhenmeyer, C. E., 2009. Intcal09 and Marine09 radiocarbon age calibration curves, 0-50,000 years cal BP. Radiocarbon 51, 1111-1150.

Siani, G., Paterne, M., Michel, E., Sulpizio, R., Sbrana, A., Arnold, M., Haddad, G., 2001. Mediterranean sea surface radiocarbon reservoir age $c$ hanges since the Last Glacial Maximum. Science 294, 1917-1920.

Sømme, T.O, D.J.W. Piper, M.E. Deptuck, and W. Helland-Hansen (2011), Linking onshore-offshore sediment dispersal in the Golo source-to-sink system (Corsica, France) during late Quaternary, Journal of Sedimentary Research, 81(2), 118-137, doi: 10.2110/jsr.2011.11

Toucanne, S., Jouet, G., Dennielou, B., Ducassou, E., Bassetti, M.A., Angue Minto'o, C., Lahmi, M., Touyet, N., Charlier, K., Lericolais, G., Mulder, T., 2012. A 130,000-year record of Levantine Intermediate Water flow variability in the Corsica Trough, western Mediterranean Sea. Quaternary Science Reviews doi:10.1016/j.quascirev.2011.11.020. 


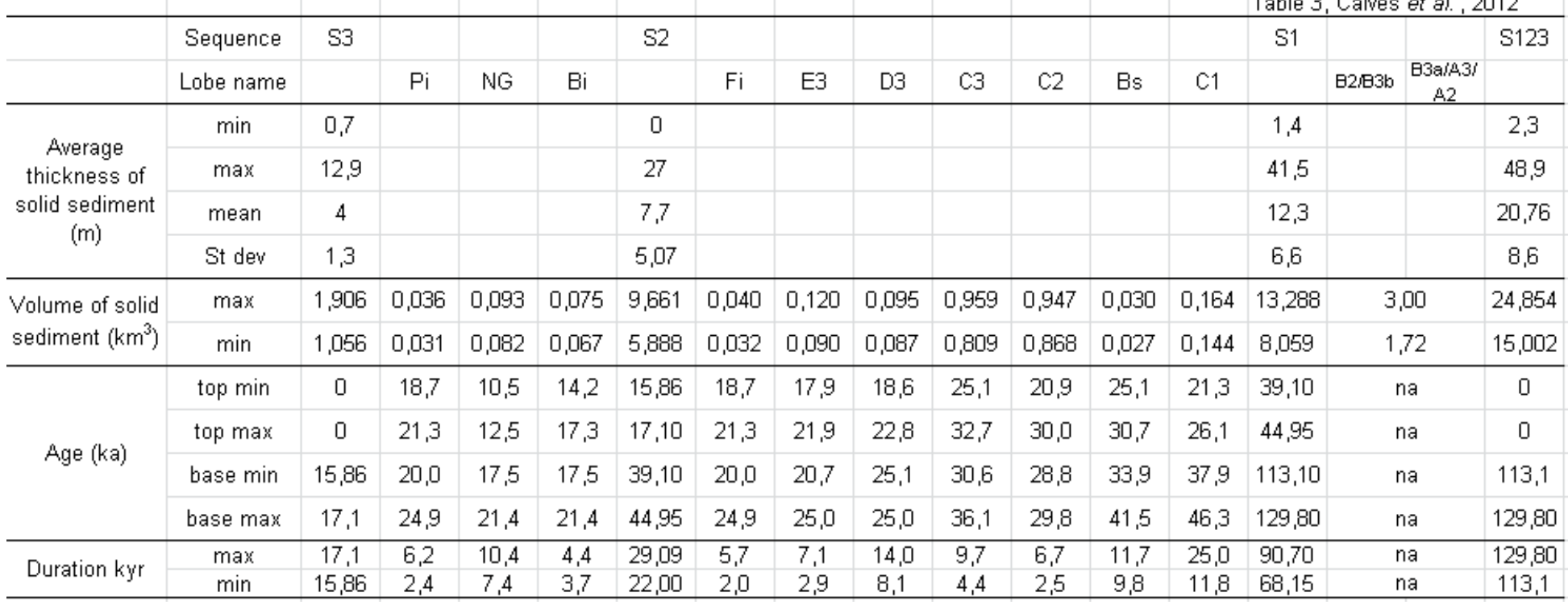

Table 3: Thickness, volumetric and age model of units and architectural elements in the Golo Basin.

Table 4, Calvès et al., 2012

\begin{tabular}{|c|c|c|c|c|c|c|c|c|c|c|c|c|c|}
\hline \multirow[t]{2}{*}{ Sequence } & \multicolumn{2}{|c|}{$\begin{array}{l}\text { Denudation } \\
\text { rate onshore - } \\
\varepsilon_{\mathrm{c}}(\mathrm{mm} / \mathrm{kyr})\end{array}$} & \multicolumn{3}{|c|}{$\begin{array}{l}\text { Mass of onshore eroded } \\
\text { solid sediment }\left(10^{3} \mathrm{Mt}\right)\end{array}$} & \multicolumn{3}{|c|}{$\begin{array}{l}\text { Mass of offshore deposited } \\
\text { solid sediment }\left(10^{3} \mathrm{Mt}\right)\end{array}$} & \multicolumn{3}{|c|}{ off/onshore ratio } & \multicolumn{2}{|c|}{$\begin{array}{l}\text { sediment } \\
\text { volume }-\varepsilon_{\mathrm{ss}} \\
(\mathrm{mm} / \mathrm{kyr})\end{array}$} \\
\hline & $\min$ & $\max$ & $\min$ & av & $\max$ & $\min$ & av & $\max$ & $\min$ & av & $\max$ & $\min$ & $\max$ \\
\hline S1 & 9 & 20 & 4,1 & 5,9 & 6,9 & 18,5 & 21,7 & 25,0 & 4,5 & 3,7 & 3,6 & 47 & 104 \\
\hline S2 & 9 & 20 & 1,4 & 2,0 & 2,4 & 12,5 & 14,8 & 18,1 & 8,8 & 7,3 & 7,6 & 101 & 219 \\
\hline S3 & 9 & 140 & 0,5 & 4,0 & 7,3 & 3,1 & 3,0 & 3,5 & 6,7 & 0,7 & 0,5 & 30 & 99 \\
\hline $\mathrm{S} 123$ & 9 & 20 & 5,4 & 8,2 & 10,4 & 33,4 & 39,5 & 46,6 & 6,2 & 4,8 & 4,5 & 68 & 129 \\
\hline
\end{tabular}

Table 4: Parameters used for the source to sink balance.

Table 5, Calvès et a!. 2012

\begin{tabular}{|c|c|c|c|c|c|c|c|c|c|c|c|}
\hline \multirow{3}{*}{ Location } & \multicolumn{11}{|c|}{ Denudation rate $(\mathrm{mm} / \mathrm{ky})$ from } \\
\hline & \multicolumn{2}{|l|}{ AFT } & \multicolumn{2}{|c|}{ Sediment budget } & \multicolumn{2}{|c|}{ Cosmogenic ${ }^{10} \mathrm{Be}$} & \multicolumn{2}{|c|}{ Incision rate } & \multicolumn{2}{|c|}{ River load } & \multirow[t]{2}{*}{ Source } \\
\hline & $\min$ & $\max$ & $\min$ & $\max$ & $\min$ & $\max$ & $\min$ & $\max$ & $\min$ & $\max$ & \\
\hline Corsica & $\begin{array}{l}\text { AFT50; } \\
\text { AHe } 25\end{array}$ & $\begin{array}{l}\text { AFT 220; } \\
\text { AHe } 200\end{array}$ & 47 & 219 & 9 & 140 & 160 & 475 & & 585 & $\begin{array}{l}\text { Fellin et al., 2005b; Kuhlemann et a!, 2009; Somme et al., } \\
\text { 2009; this study }\end{array}$ \\
\hline Period & \multicolumn{2}{|c|}{$\begin{array}{l}\text { AFT } 10-17 \mathrm{My} ; \\
\text { AHe } 7-17 \mathrm{My}\end{array}$} & \multicolumn{2}{|c|}{ last $130 \mathrm{ky}$} & \multicolumn{2}{|c|}{ last $100 \mathrm{ky}$} & \multicolumn{2}{|c|}{$80-200$ kyr } & & & \\
\hline
\end{tabular}

Table 5: Denudation rate compilation of various sources and time scale recorded from Corsica. 
Appendix B.

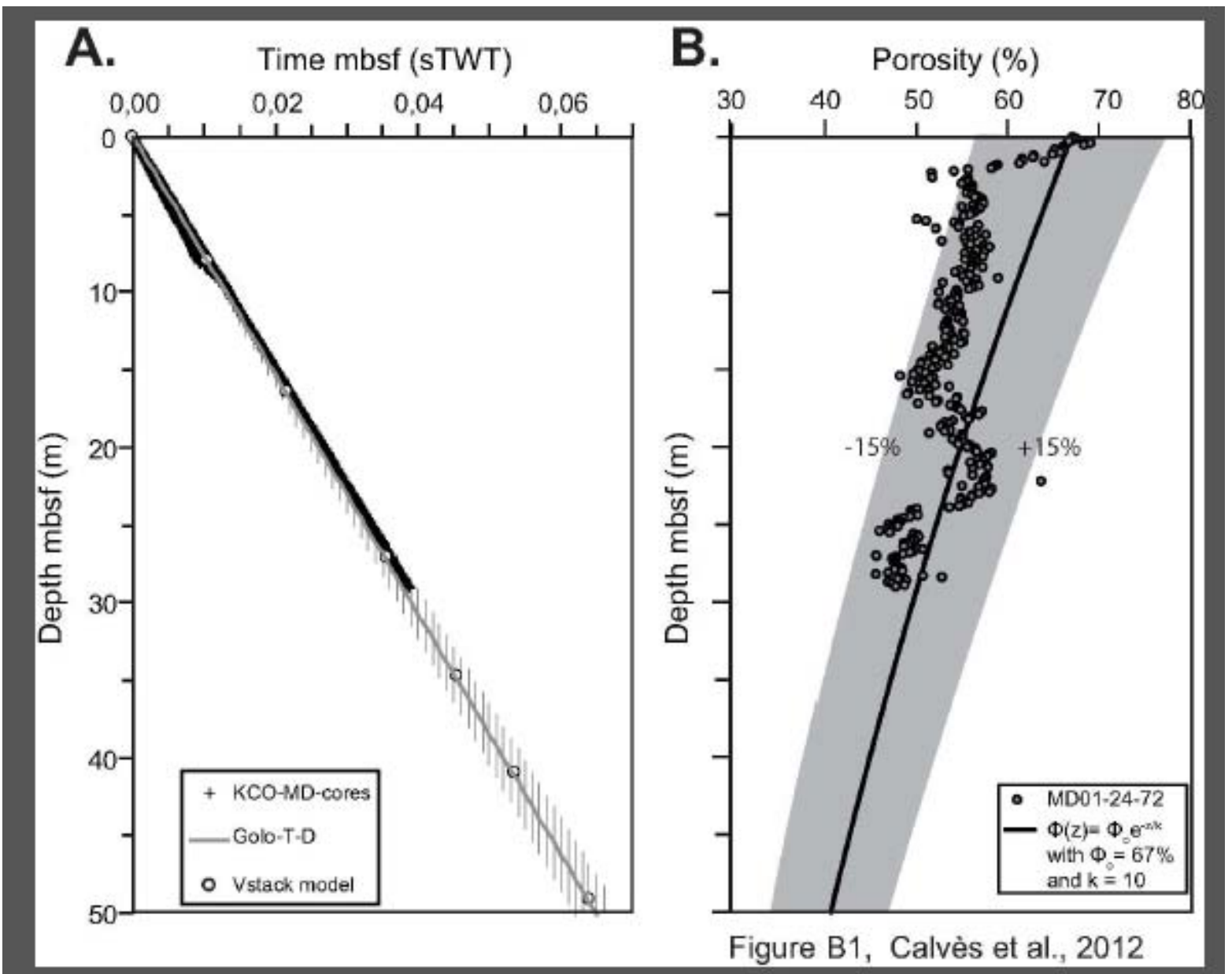

Figure B1: A. Time-depth plot from measurement $P$ wave velocity on core data $K c o$ and $M D$, and processing stacking velocity of seismic reflection data. B. Porosity decay for core MD012472 and projected range of porosity curve predicted (see text for details). 


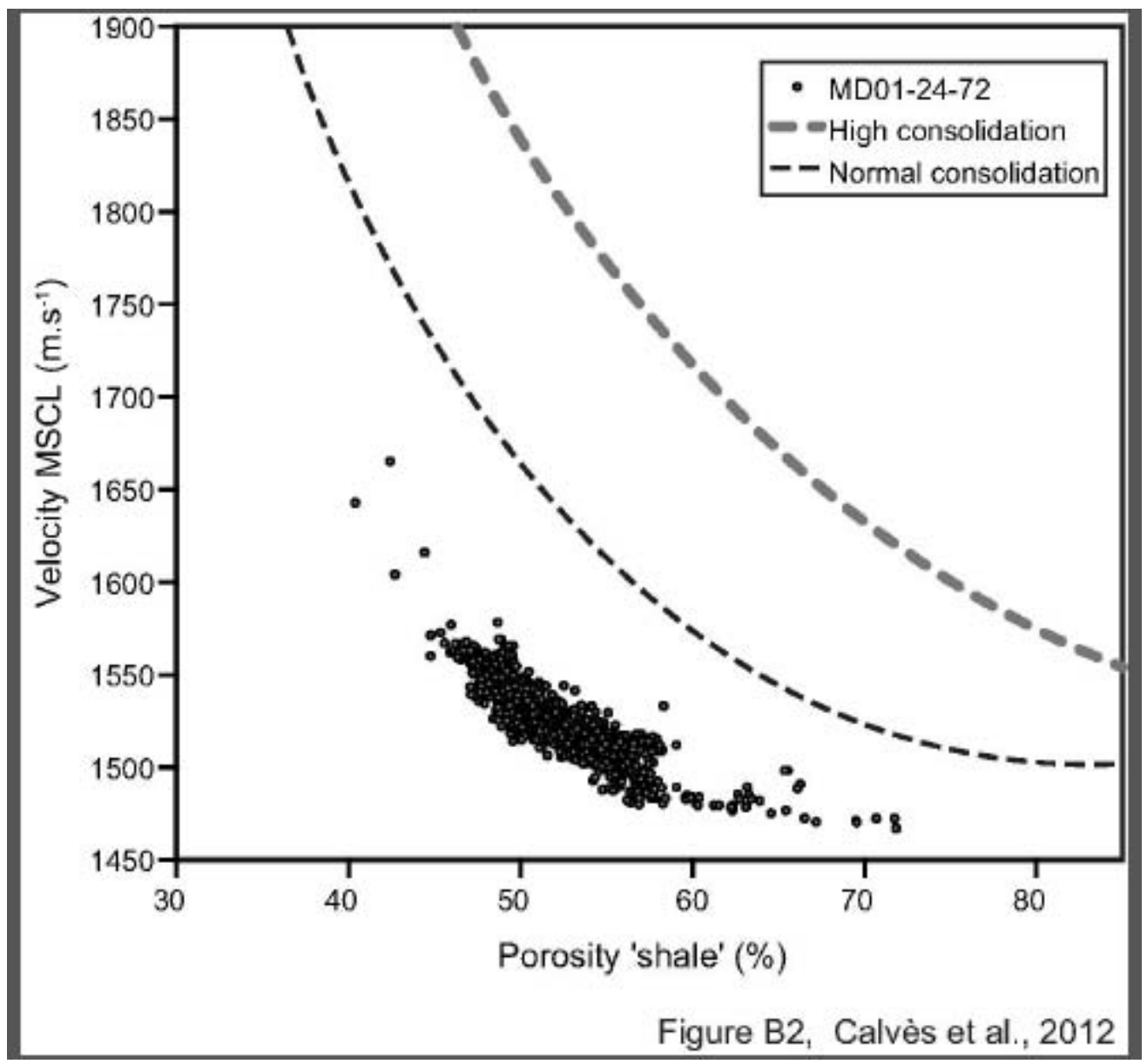

Figure B2: $\mathrm{P}$ wave velocity - porosity plot for core MD01-2472. Curves for normal and high consolidation of sediments are from Erickson and Jarrard [1998]. 